\title{
Voluntary Turnover Factors in Georgia
}

\author{
Tamar Kekutia \\ Warsaw Management University \\ Business Administration and Management Program \\ 36 Kaweczynska St. 03-772 Warsaw, Poland \\ E-mail: kekutia.tako@gmail.com
}

Received: Feb. 24, 2019 Accepted: Mar. 13, 2019 Online published: Mar. 21, 2019

doi:10.5296/ijhrs.v9i2.14395 URL: https://doi.org/10.5296/ijhrs.v9i2.14395

\begin{abstract}
The contemporary world has become VUCA (Volatile, Uncertain, Complex and Ambiguous). In the modern world people are quick to change and think quickly. In VUCA world personnel retention is one of the key points for effective, measurable, and successful results of the company's activity. In rapidly changing environment talents' recruiting and attraction in long-term cooperation is more difficult. Employee resources should be used effectively for the business success and contrary it is important employees' satisfaction for bilateral relationship and psychological contracting process. The companies should constantly pay attention how to detect personnel drain process effectively to increase business profitability. The best way to avoid personnel job leaving is to identify, analyze, and eliminate the reasons that caused it and try to prevent it. In this research reviewed all the reasons that might have prompted employees to leave the job. In Georgia financial growth and stability of firms depends on the country economic situation. It should be noted that employee financial dissatisfaction is not always the basis searching for a new job. In Georgia environmental macro factors affect to the institutional structure of companies. As time passes the private financially independent companies have staff crisis. The companies have a shortage of qualified candidate in the long run. At the same time continuously search for a new employee, development and professional growth is associated with the new financial expenses. There are different kinds of impact for human encouragement and motivation. The organizations should constantly control how stable human capital they have. There are researchers' opinions that personnel engagement in the modern world has a particular importance and it is easier to keep the employee engaged than satisfied.
\end{abstract}

Keywords: voluntary turnover, turnover factors, employee retention in Georgia 


\section{MlMacrothink}

\section{Introduction}

This new research about voluntary turnover is important for people interested in researching in this area and new understanding of the nature of modern humanity and to study its diverse nature.

\subsection{Importance}

Employee turnover is very important topic for organizations around the world. Managing retention and keeping the turnover rate is one of the most challenging issues in business. The organization should take care to each employee from the very beginning of the relationship and use the accumulated motivation theories, models, strategy to make the business more efficient. In Georgia companies are able to analyze the findings of this paper in their practical activity. Research methodology can be used to study other similar issues.

\subsection{Purpose of Study}

Purpose of study is to explore what factors are dependent on people decision to leave job voluntarily. For any organization every example of voluntarily job leaving should be point of view to analyze the management system and talent maintenance politics. In a particular case, the company maybe can't maintain the employee for the specific reasons and it is impossible at the moment, but it should be taken into consideration necessarily to avoid such a decision from another employee and eventually protect the company from massive personnel drains. This study is useful reading and practically applicable for CEO, HR Manager, HR Supervisor, Line Manager, Unit Manager, Talent Development Manager, Researcher in this area, etc. to all who want to know special efforts to maintain the talent and to use tactical methods to fight for talent.

\subsection{Subject of Research}

The subject of research is employees' opinions to explore which factors have caused voluntarily job leaving to identify working relationships gaps and to build effective management systems which is necessary to prevent voluntary outflow for business profitability and efficiency.

\subsection{Object of Research}

The object of research is persons/employees who left job voluntarily. It is noteworthy that people express their opinions more sincerely in anonymous survey which is the way of this research.

\subsection{Study Issues}

The main issue of research is the factors that influenced voluntarily job leaving. For staff maintaining purpose organizations should examine existing problems and take timely measures to eliminate them. Considering detected and researched factors organizations should provide fair and objective systems of motivation for effective human capital as the key of company's success and profitability. 


\section{Macrothink}

The study topic includes the research questions about: External Environment, Salary/Compensation, Labor Conditions, Job Satisfaction, Management Strategy, System Management, Job Location, Company Reputation, Working Environment, Personal Relationships, Job Growth/Development, Motivation, Performance Appraisal, Technology, Exit Interview etc.

\section{Literature Review}

Human capital is one of the most important resources for organization's success. Therefore, over the years the researchers have a significant study of the field related to the employee turnover and their retention models. VUCA conditions render useless any efforts to understand the future and to plan responses (Bennett, N., Lemoine, J., 2014). Even though that leaving job is caused by various types of reasons the high percentage of employee turnover rate still speaks about the employee dissatisfaction. As well as in the company where the staff drain indicator is very low, they say that organization care for the employees especially and staff is satisfied with a long-term and stable labor relationship. Job leaving classification may be voluntary (initiated by the employee) and involuntary (initiated by the company) turnover (Saridakis, G., n.d.):

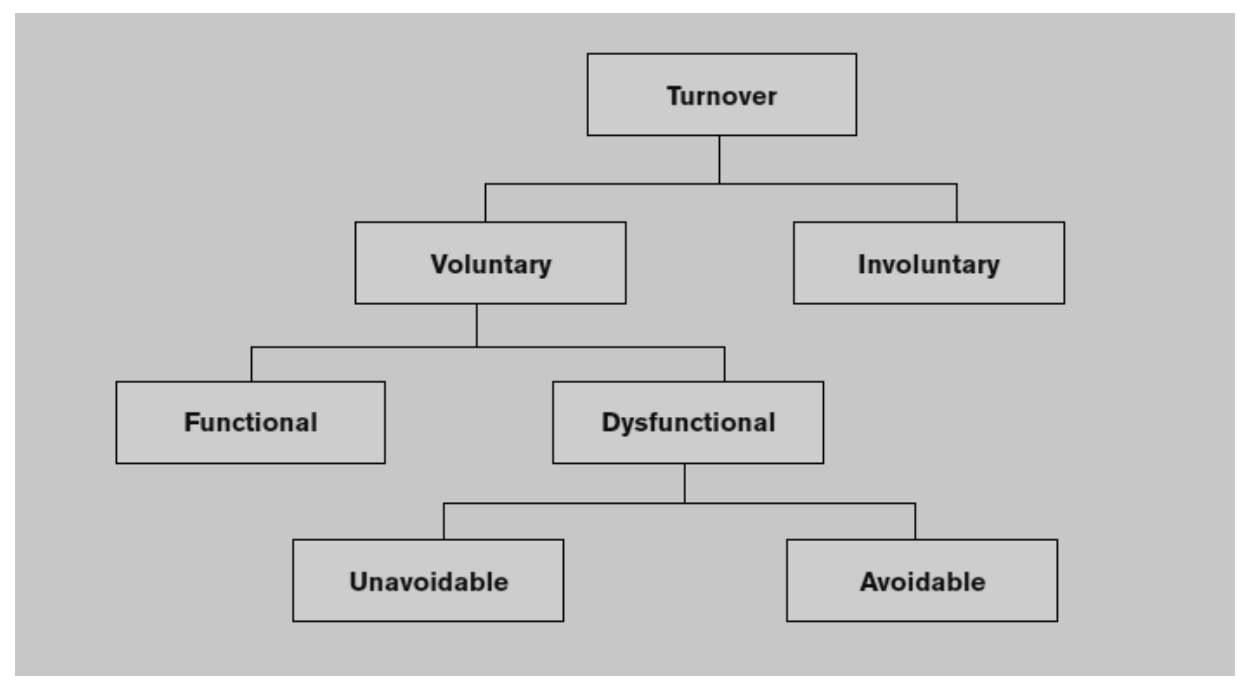

Figure 1. Turnover Classification Scheme

The types of turnover are interpreted as follows (Allen D. G., 2008):

(1) Dysfunctional Turnover - Is harmful to the organization and can take numerous forms, including the exit of high performers and employees with hard-to-replace skills.

(2) Functional Turnover - Does not hurt an organization, examples of this type of turnover include the exit of poor performers or employees whose talents are easy to replace.

(3) Avoidable Turnover - The organization may be able to make an influence and maintain employee.

(4) Unavoidable Turnover - Stems from causes over which the organization has little or no control. 
Organizations need to determine the extent to which turnover is a problem, diagnose turnover drivers and formulate retention strategies.

\subsection{Turnover Process Models}

There are in HR practice various models of Turnover Process. Among them more suitable and famous are:

\subsubsection{Organizational Equilibrium}

The first model Organizational Equilibrium published in 1958 belongs to March \& Simon. This model has attracted many researchers. Several other models have been developed and published in order to spread this first concept. Their theory is named as "Organizational Equilibrium" and determines the importance of equilibrium and inducement-contribution balance between employee and organization (March, J.G., 1991). A significant role in this equilibrium is given to the organization. According to this model employee's job leave decision related to job satisfaction and explains that individuals who are more satisfied with their current job conditions would indicate desire and effort to remain stable with their organization and grow professionally within. This theory suggested the interaction between parts and is directed to mutual satisfaction.

\subsubsection{Met Expectations Model}

Model of Met Expectations authored by Porter \& Steers in 1973 and it is still an important survey review and knowledge in organizational psychology and organizational behavior. Mentioned classic and basic definition of met expectations model specifies that individuals compare their before entry expectations about job and post-entry perceptions (Wanous, J. P., Poland, T. D., Premack, S. L., Davis, K. S., 1992). This concept determines that people always compare their expectations to the real situation in the organization associated with salary, promotion, recognition, collective collegiality, development possibility, working environment etc. The facts that are incompatible with the expectations have a great impact on the employee to have a desire to leave job voluntarily. According this model satisfaction is as intermediary in relationship between unmet expectations and leaving the job. Met Expectations model also determines need for organizations to conduct expectations survey for new recruits, to explore this important information. Porter and Steers also explain that low levels of expectations are desirable because individuals will have a feeling of high satisfaction at new job. This model actually has been developed in various forms by researchers at various times depending on the importance of topic.

\subsubsection{Intermediate Linkages Model}

In intermediate linkages model is defined importance of intermediate linkages in the relationship between job satisfaction and employee turnover (Mowday, R. T., Koberg, Ch. S., McArthur A. W., 1984). First, Mobley in 1977 significantly presented in this model variables that link job attitudes with actual turnover behavior in the turnover process. Author's vision of this work noted that job attitudes directly related to withdrawal cognition associated with decision to leave job and only indirectly related to actual turnover behavior. Author identified 
a more comprehensive withdrawal process and explained sequence of employee steps before receiving the final decision to stay in organization or leave. Mobley in second model in 1979 tries more deeply study and identify wide range of factors that can initiate employee's desire to leave an organization. This second model was less concerned with intermediate linkages in decision receiving process than with relationships between job-related and non-job factors which is the basis for thinking about leaving the job. Both models contributed new study to organizational knowledge about the personnel drain. According author's opinion the best predictor of turnover should be the employees' behavioral intention to leave the organization.

\subsubsection{Alternative Linkages Model}

Hom \& Griffeth in 1991 proposed alternative linkages model in which withdrawal cognition mediate job dissatisfaction and exit relationship. In this model the factors are responsible for the initiation of the turnover process like job dissatisfaction that is displayed after employee selection (Hom, P. W., Griffeth, R. W., 1991). Model of turnover recognizes the independent effects of job satisfaction and organizational commitment on turnover intentions. This integrative model defines above mentioned variables in the construct withdrawal cognition and this two work attitudes are conceptualized and have response effect on each other, while also have direct and independent effects on intention to quit. Authors also developed IQ (intention to quit) instrument and they most importantly considered need for its measurement in the organization. Hom \& Griffeth in their later work in 1995 found the attitude between age and personnel drain. They emphasized the age of the employee and concluded that "Older employees with long tenure in a company quit less often than younger and short-tenure employees did".

\subsubsection{Causal Model of Turnover}

Price \& Mueller's causal model of turnover represents a multilevel study theory related to job quit, that means to study all the determinants related to leaving decision. According this model clarified the need of analysis of causal accounts which is helpful and informative because it defines dynamic image of turnover. The model offers an account for all causal relationship and explains which determinants are depended on and operate to produce turnover (Price, J. L., Mueller, C. W., 1981). Price also supports a negative relationship between age and turnover and defines that "younger members usually have higher rates of turnover than do older members". By casual model the following 11 determinants produce variations in turnover: Opportunity, Routine work, Participation, Instrumental communication, Integration, Pay, Distributive justice, Promotional opportunity, Professionalism, General training, Kinship responsibility.

\subsubsection{Attraction-Selection-Attrition Model}

Schneider's model determines that the people make themselves working environment and they create in the organization corporate culture, climate and the best practices. This theory is closely related to psychology and people socialization process. Three - part model explains how collective characteristics of individuals define how they fit within an organization (Schneider, B., 1987). In 1995 the ASA (Attraction-Selection-Attrition) framework was 
updated by Schneider. Author mentioned that the person is particularly important in the organizational context and by new dimension employees are responsible for the organizational structure, internal processes and culture. Attributes of people, not the nature of external environment, or organizational technology, or organizational structure, are the fundamental determinants of organizational behavior (Schneider, B., 1987). According ASA model each part is interpreted as follows (University of TWENTE, n.d.):

(1) Attraction: People are differentially attracted to careers as a function of their own interests and personality.

(2) Selection: Organizations select people who are compatible for many kinds of jobs and who have many common personal attributes, people who possess knowledge, skills and abilities that are similar to existing employee.

(3) Attrition: This part shows opposite side of attraction. People when don't fit an organizational environment they make decision to leave job. People when leave the organization in the working environment stays a more homogeneous group and employees who left were initially attracted to the organization.

This hypothesis states that individuals in the same organization should have more similarities in shared personality, than members of different organizations. ASA model is very useful for recruitment process to attract the right audience, which candidates are similar to the existing employees and conforms to a homogeneous organizational culture.

\subsection{Methods of Turnover Reduction. Opportunities for Learning}

Many researchers have highlighted that HC (Human Capital) investment in training improve employee engagement at work, because it can have real value for the organization and a greater impact on employee outcomes. Research has shown that engaged employees are 87 percent less likely to leave an organization. Also, employee training has a positive relationship on employee knowledge and workforce commitment. There are ways for attaining new knowledge.

(1) Workplace Learning - Workplace learning is largely experimented method in practice. Socialization on the job and interaction with colleagues can help facilitate workplace learning. Encouraging employees also create content for their further successive results and skills development.

(2) Self-directed Learning - Individuals review what they have learned, what they have achieved, what their goals are, how they are going to achieve those goals and what new learning they need to acquire. Self-directed learning is becoming increasingly attractive in rapidly changing world. Self-directed learning may lead to improve firm performance.

(3) Mentoring - mentoring is traditionally a process in which an experienced person (the mentor) guides another person in the development of her/his own ideas, learning and personal/professional competence (Klinge, C. M., 2015). There should note that mentor's own experience and qualification is particular value for the new employee. 


\section{Macrothink}

International Journal of Human Resource Studies

ISSN 2162-3058 2019, Vol. 9, No. 2

Mentoring also promotes on-the-job learning and can act as a complement to formal training (Armstrong, 2017).

(4) Electronic Learning (E-learning) - involves use of computer, networked and web-based technology to provide learning material and guidance to employees (Armstrong, 2014). Web based learning portals is established in many universities. Maybe also use learning courses via application. E-learning programs are not as effective for developing soft skills such as team-building.

(5) Employee Development and Career Management - This section explains importance of employees' new opportunities for more learning and their career succession. Plan of career objectives helps employees to achieve organizational goals. Employers must ensure that employees have a career path in the organization. Career plans must put in place and be aligned with employees' goals in order to reduce employee turnover and to increase employee engagement (Byrne, Z. S., 2014). The researchers examined that participation in tuition reimbursement reduces turnover while employees are in school. The results also demonstrated that, for individuals who enter a firm and who are not already college graduates, tuition reimbursement program is a particularly effective way to encourage employees to enhance their career prospects within the organization. Various studies also showed that employee turnover increases when individuals earn their graduate degrees.

(6) Non-cognitive Abilities - Many researchers have highlighted about non-cognitive skills, such as character skills, personality traits, goals, motivations and preferences which are growing in value. Researches has examines the role or personalities, attitudes and mindsets in relation to human and social capital and workplace outcomes. A proactive personality is positively associated with interpersonal helping and negatively associated with turnover intention. There are a number of studies that have examined the relationship between psychological capital and employee outcomes. (Luthans, F., 2008) recommend for employees periodical short training that includes confidence-building sessions and goal-setting sessions to enhance their efficacy, optimism and hope.

\subsection{Refreshed Model for Engagement}

After two years research based interviews with hundreds of clients Deloitte University Press suggests to us new model for engagement for turnover reduction (Bersin, J., 2015): Meaningful work, Hands-on management, Positive work environment, Growth Opportunity, Trust in leadership. 


\begin{tabular}{|c|c|c|c|c|}
\hline $\begin{array}{l}\text { Meaningful } \\
\text { work }\end{array}$ & $\begin{array}{c}\text { Hands-on } \\
\text { management }\end{array}$ & $\begin{array}{c}\text { Positive work } \\
\text { environment }\end{array}$ & $\begin{array}{c}\text { Growth } \\
\text { opportunity }\end{array}$ & $\begin{array}{l}\text { Trust in } \\
\text { leadership }\end{array}$ \\
\hline Autonomy & $\begin{array}{c}\text { Clear, transparent } \\
\text { goals }\end{array}$ & $\begin{array}{l}\text { Flexible work } \\
\text { environment }\end{array}$ & $\begin{array}{l}\text { Training and } \\
\text { support on the job }\end{array}$ & $\begin{array}{c}\text { Mission and } \\
\text { purpose }\end{array}$ \\
\hline Select to fit & Coaching & $\begin{array}{l}\text { Humanistic } \\
\text { workplace }\end{array}$ & $\begin{array}{c}\text { Facilitated talent } \\
\text { mobility }\end{array}$ & $\begin{array}{l}\text { Continuous } \\
\text { investment in } \\
\text { people }\end{array}$ \\
\hline $\begin{array}{l}\text { Small, empowered } \\
\text { teams }\end{array}$ & $\begin{array}{c}\text { Invest in } \\
\text { management } \\
\text { development }\end{array}$ & $\begin{array}{l}\text { Culture of } \\
\text { recognition }\end{array}$ & $\begin{array}{l}\text { Self-directed, } \\
\text { dynamic learning }\end{array}$ & $\begin{array}{c}\text { Transparency and } \\
\text { honesty }\end{array}$ \\
\hline Time for slack & $\begin{array}{c}\text { Modern } \\
\text { performance } \\
\text { management }\end{array}$ & $\begin{array}{l}\text { Inclusive, diverse } \\
\text { work environment }\end{array}$ & $\begin{array}{l}\text { High-impact } \\
\text { learning culture }\end{array}$ & Inspiration \\
\hline
\end{tabular}

Figure 2. Five Elements Drive Engagement

\subsection{Recent Years Trends}

What factors predict employee retention? For example, as it's known the typical American worker changes employers 11.7 times before age 48 and business has expenses an average of 21 percent of employees' annual salary to replace workers. There are two types of job transitions: Internal and External:

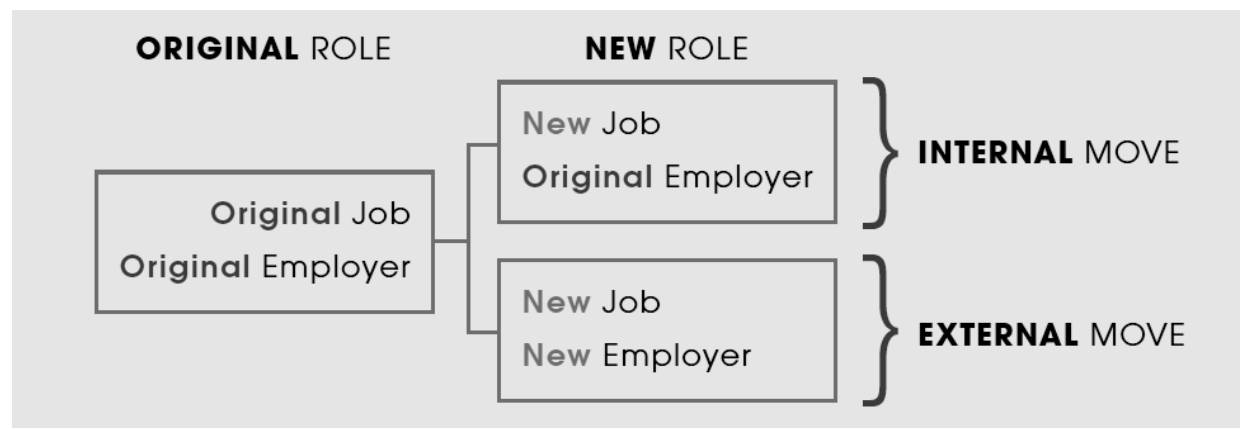

Figure 3. Two Types of Job Transitions: Internal and External

According to GLASSDOOR economic research report every job transition adds another line to employee resume and it also opens the door to new career challenges and opportunities: promotion, better pay, fresh start with a new employer, move to a new location, entry into an entirely new profession (Smart, M., Chamberlain, A., 2016).

GLASSDOOR researchers extracted from 2007 to 2016 unique 4,592 resumes shared by job seekers and survey result presented basic facts about career transitions. 


\section{Ml Macrothink}

Table 1. Months Spent at Original Job

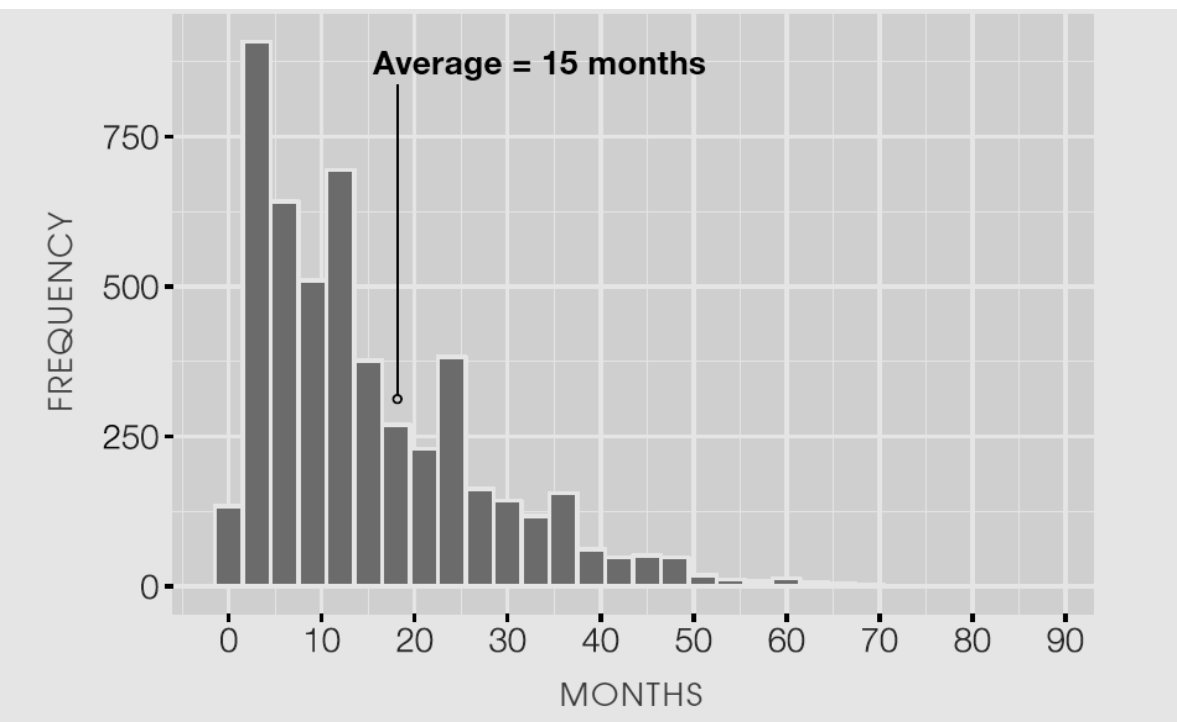

Source: GLASSDOOR economic research report (2016)

(1) Trend 1: most employees leave their company when changing jobs. Employees quit current job when they are ready to move on to their next job.

(2) Trend 2: most employees change jobs frequently: researches explain that many employers review and promote employees on annual cycle and workers change jobs or leave for a new employer at these annual points

(3) Trend 3: some industries change jobs far more often. by above mentioned report the most frequent job changes is in the construction industry, repair and maintenance and employees in this sector change jobs every 10.6 months on average. For example, most construction work is seasonal and workers routinely change jobs and employers after each project is completed. In public sector roles is more stable.

(4) Trend 4: when workers change jobs, they usually get a pay raise. Employees change jobs for many reasons. Some are promoted to more senior and upper positions or some make horizontal moves into new job functions.

(5) Trend 5: when workers leave employers, it's usually for better culture. Researchers examined six measures of company culture: overall rating, career opportunities, compensation and benefits, culture and values, work-life balance and quality of senior management.

In 2002 Taylor and his colleagues interviewed 200 people who had recently changed employers about why they left their last job (Torrington, D., Hall, L., Taylor, S., 2005). There are three the most common reasons:

(a) Dissatisfaction with the conditions of work

(b) Perception that they were not being given sufficient career development opportunities

(c) Bad relationship with their immediate supervisor.

In 2000 three scientists combined all existing literature on employee turnover. This resulted in a meta-analysis of over 60.000 employees (Vulpen, E. V., n.d.). Research findings are presented in info graphic: 


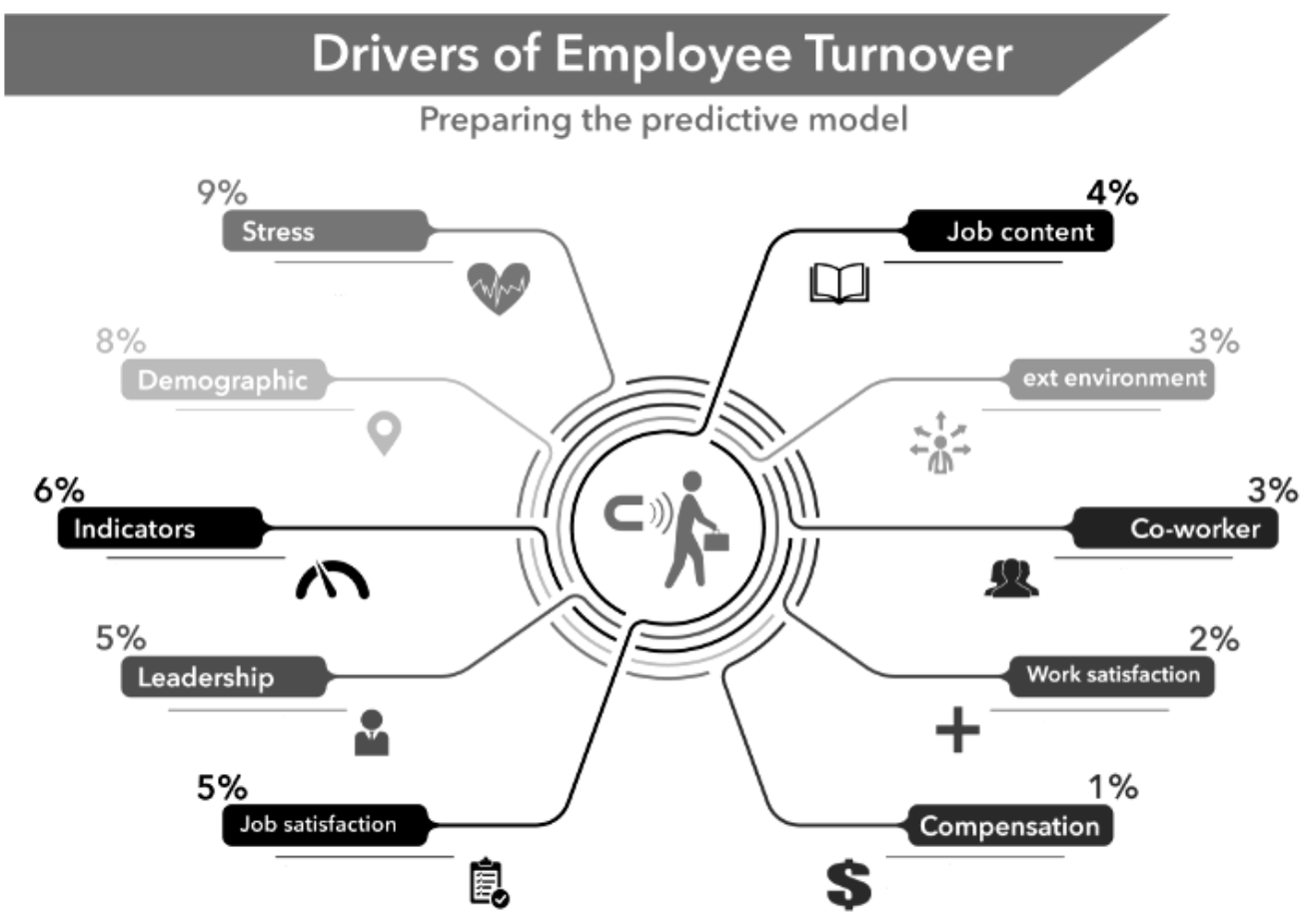

Analytics in HR.com

Figure 4. Drivers of Employee Turnover

On the basis of various research and publications of AIHR it is possible to indicate factors, which affect on the job leaving: External Environment, Salary/Compensation, Labor Conditions, Job Satisfaction, Management Strategy, System Management, Job Location, Company Reputation, Working Environment, Personal Relationships, Job Growth/Development, Motivation, Performance Appraisal, Technology, Exit Interview etc. The above listed factors are the basis of practical research in Georgia.

According to AIHR (HR Analytics Academy) analytical information people then decide to leave when they reach the maximum level of potential realization (Vulpen, E. V., n.d.). 


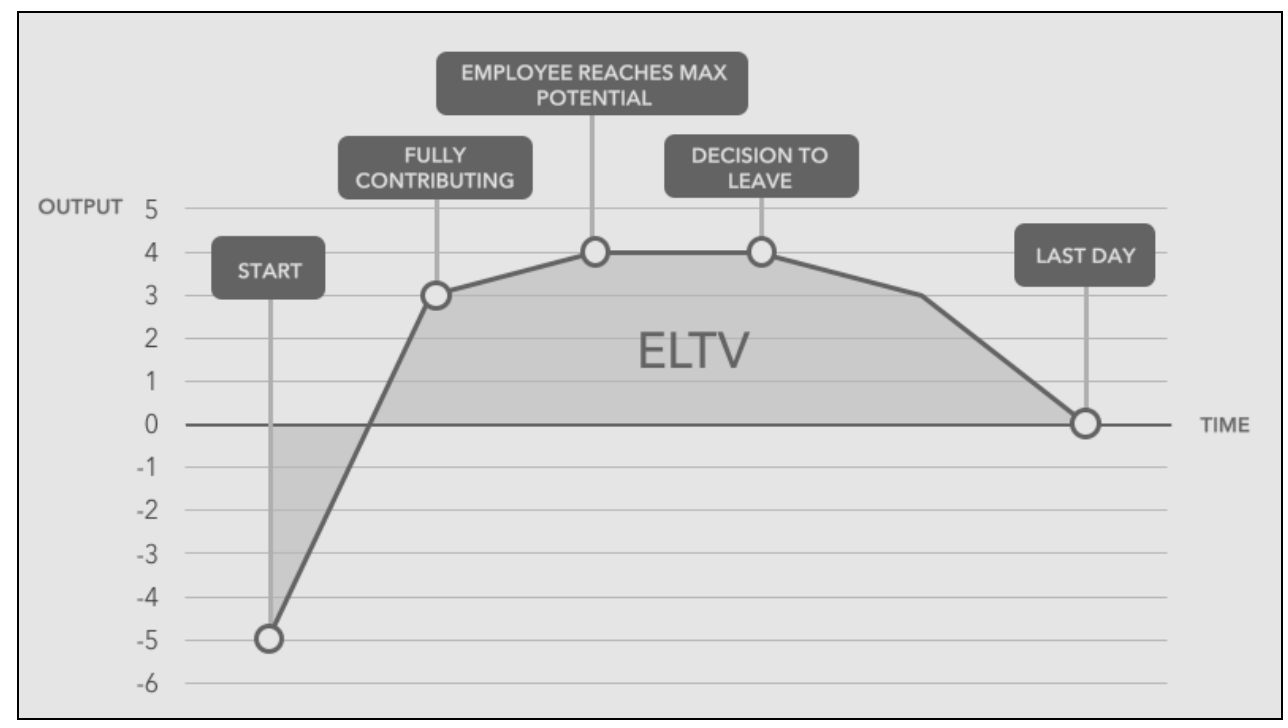

Figure 5. Employee Life cycle

According Harvard Business Review the top things millennial looking for in a job (Goler, L., Gale, J., Harrington, B., Grant, A., 2018)

(1) Opportunity to learn and grow

(2) Quality of manager

(3) Quality of management

(4) Interest in type of work.

As it is known, client companies has reduced turnover by $45 \%$ by implementing Stay Interviews and solving the unique needs for each individual employee.

Turnover often starts with poor selection decision, compounded by inadequate training, insensitive appraisal and inequitable pay (Dessler, G., 2013). According to above mentioned study, experts from the consulting company DDI (Development Dimensions International) and the employment firm ROBERT HALF INTERNATIONAL suggest building comprehensive retention programs around the following steps:
(a) Selection
(b) Professional growth
(c) Provide career direction
(d) Meaningful work and ownership of goals
(e) Culture and environment
(f) Promote work life balance. 


\section{Macrothink}

International Journal of Human Resource Studies

ISSN 2162-3058

2019, Vol. 9, No. 2

\section{Methodology of Research}

This master thesis is analytical study that examines "Voluntary Turnover Factors in Georgia" based on its actuality. The goal of study is to determine which factor(s) has influenced the employee's decision to leave the employer. The purpose of this analytical study is to analyze the case of each respondent and explain how and why it is happening in the organization. The goal of research is to get acquainted existing relationships between the factors influencing and the job leave decision. This applied research will be very important for the academic sector for further educational, scientific or HR practical purposes. The survey includes data collection, processing, cleaning, analysis, interpretation of the results obtained and the general judgments (final) conclusion.

\subsection{Method of Research}

Qualitative and Quantitative mixed research has been used as a research process. Research logic is represented in the form of induction research aimed at studying and generalizing private facts. The research is oriented to investigate practical issues and real problems in organization.

\subsection{Data Collection Process}

For the survey is used "Quota Sampling" method. The formation of quoted selection is as follows: depending on the peculiarities of the research task and the number of respondents is initially determined. The respondent is selected randomly from relevant target audience to explore why employee left the job. It's necessary to find the most appropriate respondents, also ask them to invite friends with a similar case (who left job voluntarily). Thus, networking is formed. The "Snowball Sampling" method is used, since the number of respondents increased gradually over the months (Biernacki, P., Waldorf, D., 1981).

\subsection{Main Condition to Participation}

In the survey can take a part minimum 16 year-old person who have voluntary left own job in 2018, in Georgia. For participation it hasn't attention to the skin color of respondent, sexual orientation, racial identity, title or property, social origin, nationality, religion, political beliefs etc. For the participation it does not matter the job position and/or education and/or income level of respondent, also full or part-time employment. If one person has left several jobs in 2018 , in such case participant can give information about the last job. The research provides collecting the information about employees who have been worked in companies registered in Georgia.

\subsection{Quantity of Respondents}

According to "Quota Sampling" method the study considers analysis of 70 participants' opinion (quantitative survey of 50 respondents and qualitative survey of 20 respondents). The process of data collecting lasted 5 months (July 01 - November 30, 2018).

\subsection{Survey Design}

The online quantitative questionnaire includes 4 sections: 
(1) In section \#1 introduced an introductory part where is presented the information about the researcher, university and the research goals.

(2) In section \#2 presented 4 questions about respondent's demographic data: gender, marital status, having children and age.

(3) In section \#3 presented 4 questions in order to analyze the employment statistics of former job: duration of employment, relatives at job, employment field, position level.

(4) In section \#4 presented 17 questions to research and analysis the factors affecting the decision on.

Research question is focused on factors such as: External Environment, Salary/Compensation, Labor Conditions, Job Satisfaction, Management Strategy, System Management, Job Location, Company Reputation, Working Environment, Personal Relationships, Job Growth/Development, Motivation, Performance Appraisal, Technology, Exit Interview etc.

\section{Result Analyzing and Discussion}

\subsection{Demographic Data}

According to the studies, there is no big difference between men and women, both genders are affected from some factors almost equally to leave the job. Accordingly, organizations must be taken caution to lightly verify with both genders their motivation reasons. It should be taken into consideration that unmarried people are more easily able to leave the job and ready to deal with changes. However, there is a high probability that a married person will leave the job immediately when comes better option for alternative job. Married person due to more responsibility in the family will be waiting for just another option in unbearable conditions. When a married person shares to the second half own work stress, he/she feels supporting the need to change the environment.

Table 2. Data of Respondent's Children

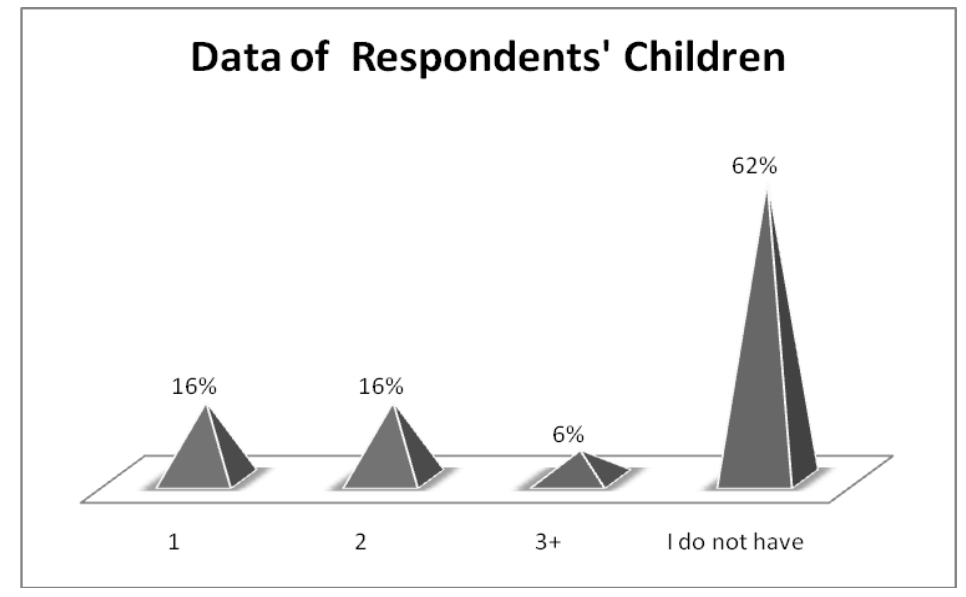

Source: Developed by the Author

It should be taken into consideration, when a person has child/children and is worried about job dissatisfaction, before a new real job she/he thinks about the family and keeps patients 
consider Georgian situation of social conditions. The mother is terrible for the lack of child's attention and the balance of life is a prerequisite for losing her job. Here is the importance the couple's support and promotion. When a person does not have a child / children, it is easier to make decisions about career changes. It should be noted that single people are more focused on career and development rather than parent because he/she only hopes for himself/herself.

\subsection{Respondent's Age and Millennial Generation}

According to research, age of employee is significantly linked to the job tenure. In the modern epoch generations have been named different names: "Millennial" are people born between the years of 1980 and 1995, otherwise known as "Generation Y" or internet generation (I-Gen). "Generation Z" is a young generation that born between 1991-2001 years. Research has shown that for millennial is particularly difficult on one place for a long stay, and they are constantly in search of new challenges and changes. If the company does not offer them an interesting job, they start off looking such an environment. Millennial approximately in a 25-30 year range have thought that they are ready for new challenges, and they are driven by ambitions. People under 25 still feel the lack of experience and it is possible to maintain such a worker for a few years. Over 30 years people are looking for better conditions than many years of experiences, more than challenges. They evaluate themselves the background of the experiences already advanced and appreciate the dynamics of the organization's development. At this age, the person analyzes the mistakes of past years in business relationships, is trying to evaluate its qualities, skills and experience and determines the value of own candidacy in labor market. People over the age of 40 are afraid of the future and have a more stable job, because in many published statements in Georgia it's the marginal age of the contestants. After 40 years, employment becomes more difficult, but it is also related to the field.

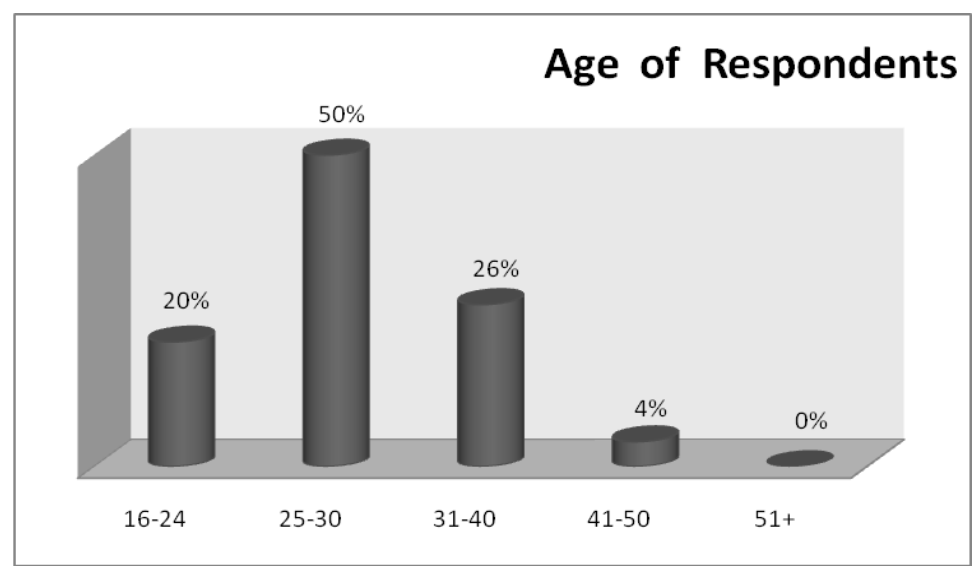

Figure 6. Respondent's Age

\subsection{Job Tenure}

According the Georgian legislation, the first six months is the examination term. The organization should provide the maximum assistance to the employee within the first 6 months to adapt and convince him/her that expectations were justified. The candidate seeks to 
evaluation the examination time, waiting to evaluate his/her work, waiting for a 1-year contract and the required benefit after exam period. The employee when convinced that his/her expectations are not justified or correctly didn't assess his/her skills by the management, she/he will soon leave the job after the examination period. So employers have to pay special attention to employees after 6 months. The biggest case is when the employees leave the job during 1-3 years. At the time the term of the contract already is clear, what the organization offer to employees. At this time, when the employee decides to go, he/she feels incompatible with expectations. Patience is often due to go into slow but when the employee knows that the organization's root change is not possible in a short term, prefers to change in time. If the organization within 1-3 years cannot afford to replace an employee with a new challenge, he/she feels hunger of novelty and finds it somewhere else. In addition, in the long term relationship, the lack of appreciation leads the work dissatisfaction. As soon as employee considers that in long-term cooperation she/he is not promoted, she/he has unfairly low wages, future changes have a little hope, that's why they take a decision to leave. 30 months after the contract is considered to be permanent in Georgia. If employee is employed in a life-long contract, and she/he doesn't see recognition, promotion, good salary, she/he also thinks about leaving. The employee is looking for benefits.

Table 3. Duration of Employment

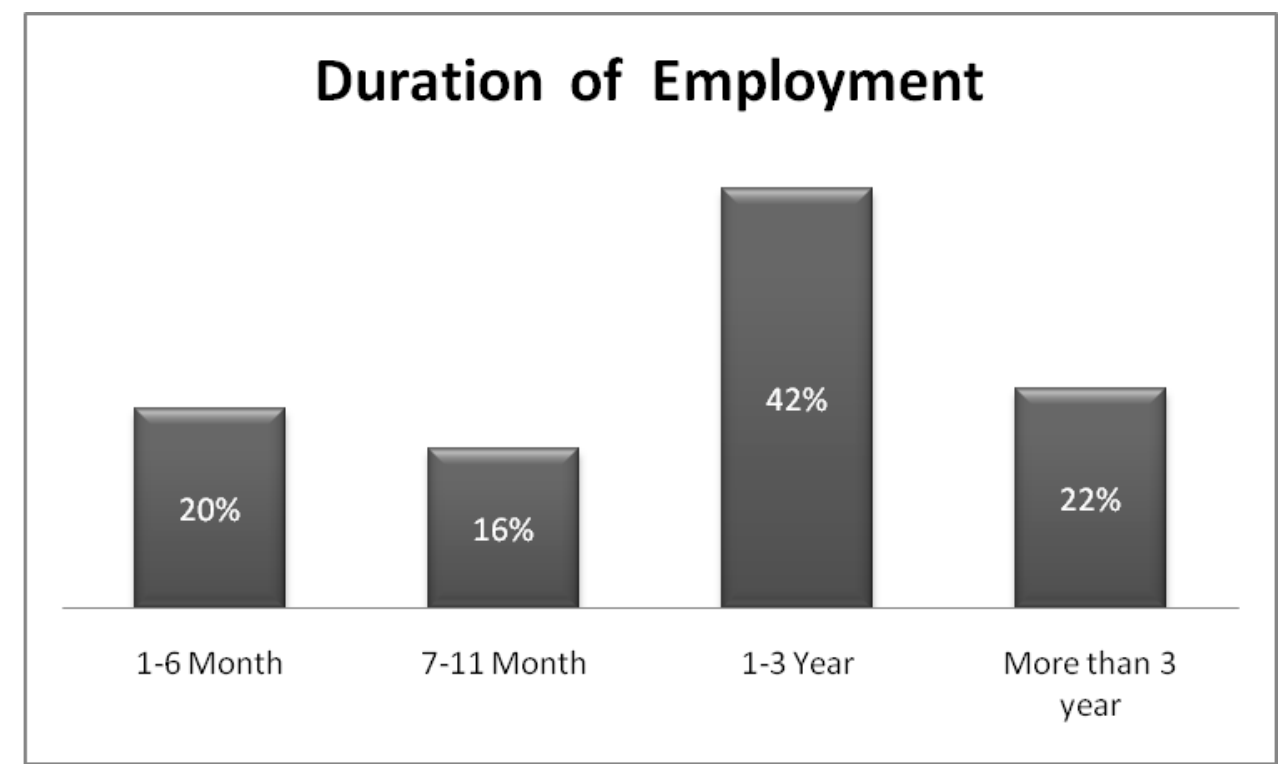

Source: Developed by the Author

\subsection{Kinship Relationship}

The employee feel more free to choose a job if it happens within a transparent recruiting process, based on the competition and at the times he/she makes correct analysis of assessment of organization. New employee is more capable to demonstrate its capabilities in the new arena. Also, the ability to monitor new employee's opportunities is more interesting when organization has it selected through competition. This is a new experience for both HR and other supervisor person. In general, employment with relatives in the job is badly perceived by the organization's staff. People employed by a kinship are more relied on 


\section{Macrothink}

relatives and not to the organization. It is better, when the candidate meets to all conditions within competition and does not take into consideration kinship relationship. Also, kinship connections impede the introduction of a fair motivation and assessment system in case of any model.

Table 4. Relatives at Work

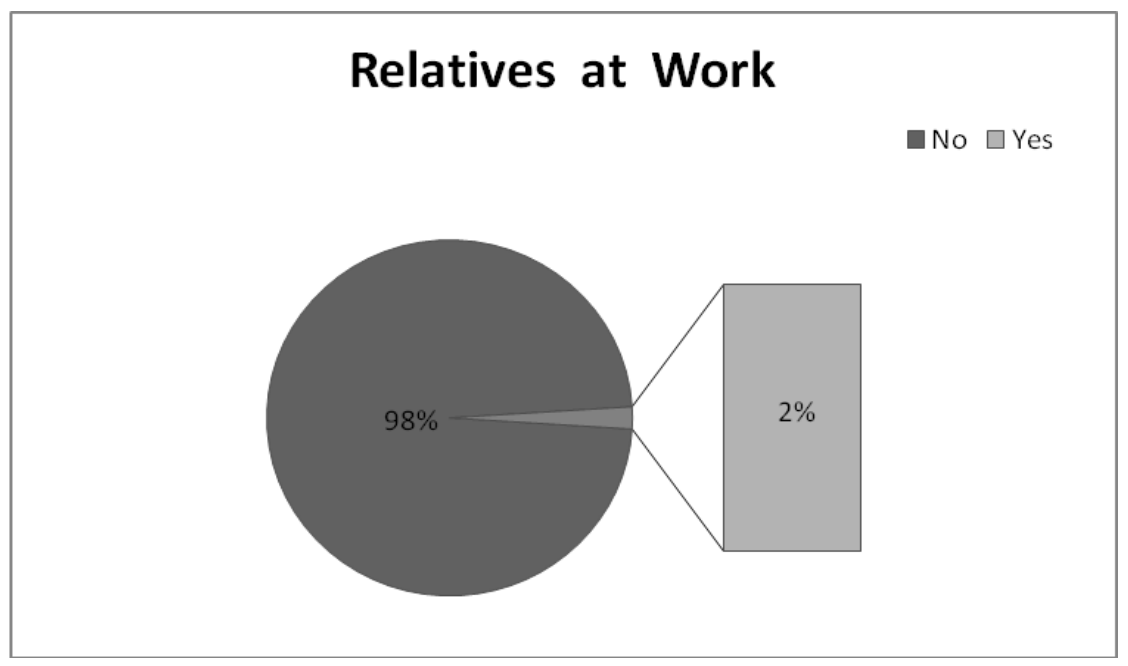

Source: Developed by the Author

\subsection{Position Level}

Depending on the result of research, it is necessary to maintain a higher position's employees. When a person employed on the head positions, she/he need more freedom than high positions and not only high salary. Employee already knows the organization's founders and the expected prospects. People working in the middle position mostly leave jobs due to conditions and relationships. People working on low positions do not feel part of the organization's living organism, and they are easily replaceable. They need to know organizational goals and the feeling of fairness of promotion stages.

Table 5. Level of Occupied Position

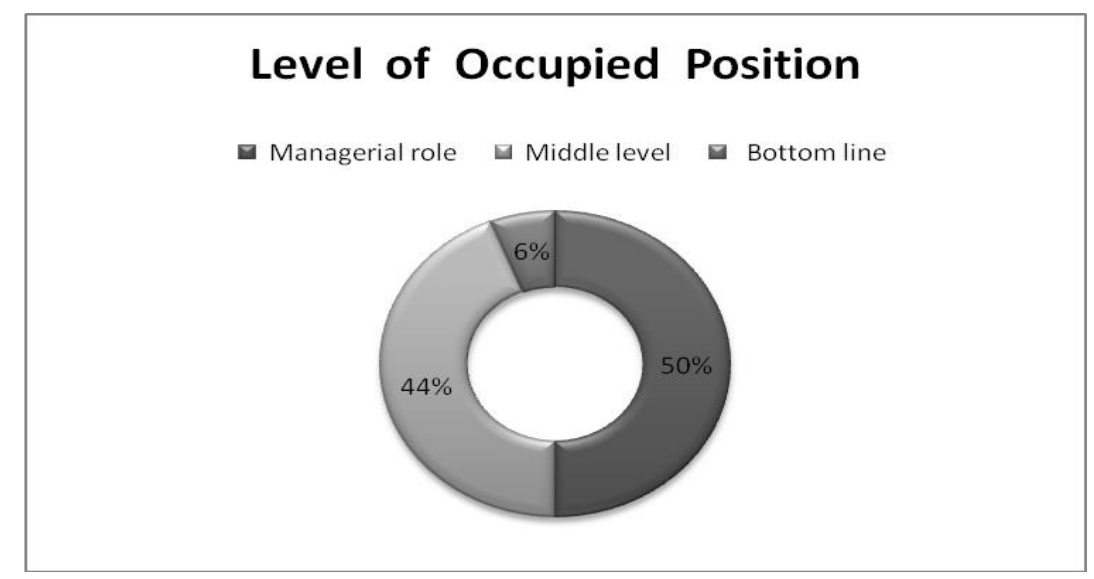

Source: Developed by the Author 


\subsection{External Factors}

As a rule, when the employees begin to search new job, it is already late to keep them. There is a different chance to see a better job. The organization should address its attention before finding a new job. Nowadays, the work and life balance breaches causes to refuse to personal plans, which is why the person is slowly developing.

Table 6. External factors which influenced respondent's decision

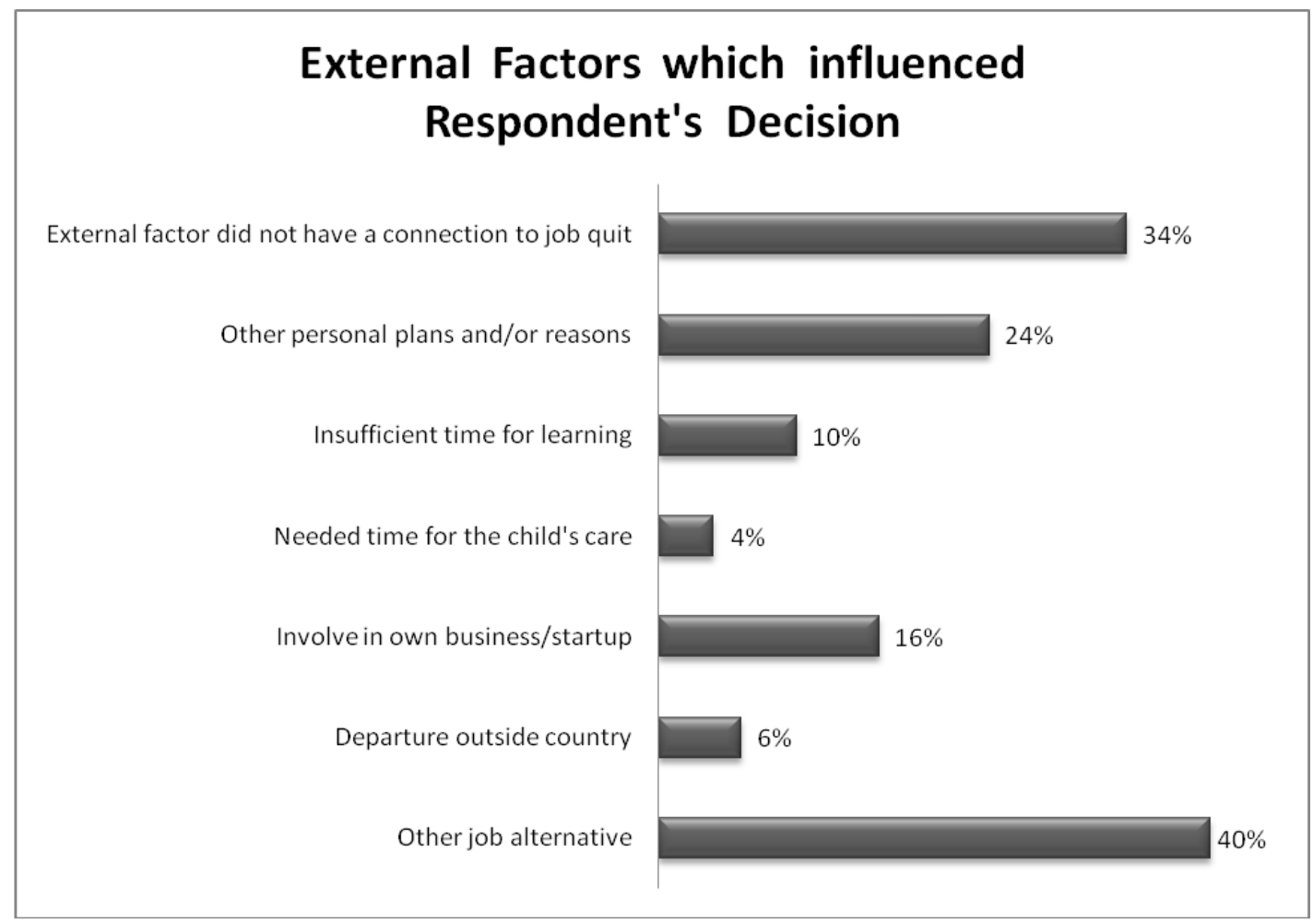

Source: Developed by the Author

Employee has spent all her/his time in the job and does not have time for hobby, for favorite activities and that's certainly the reason for leaving. Implementation of benefits will slow down the employee for a long time. Often people spend most of their time at work, especially when working on a high position. They think a lot about the obligations and new ideas. In case of success, the organization cannot afford them financially encouraging salaries at the appropriate level. At this time, the employee seeks the way that is called personal business/startup. Why? Because professionals are free to choose, because they can risk, because the mistakes will not be punished, because they can generate all ideas, because they are ready for the news. Job dissatisfaction and low salaries lead to leaving the country.

\subsection{Salary/Compensation}

Depending on the results of research, the employee's de-motivation is associated to dissatisfaction with the salary. People often prefer to be not employed than to have low salaries. Therefore, there are cases where HR professionals say, there is very little flow on job interviews. Very high competence candidates always say the minimum wage limit, they know 


\section{Macrothink}

International Journal of Human Resource Studies

ISSN 2162-3058

2019, Vol. 9, No. 2

their own price. They assure employers to hire them how will be organization's success. When a candidate needs more job than an organization needs a candidate, the company is always trying pay as little as possible. Low-paid candidates are more likely to go from the company. They can be easily replaced by new force in the labor market. The best solution is when employer offer to employees more salary than on the market and never delaying salary payment. When employee searches the market, she/he will not go to a low salary and will be in the current job for a long time. That means that the company should control the labor market, that other employer does not offer more salaries on this position.

Table 7. Salary/Compensation Related Factors

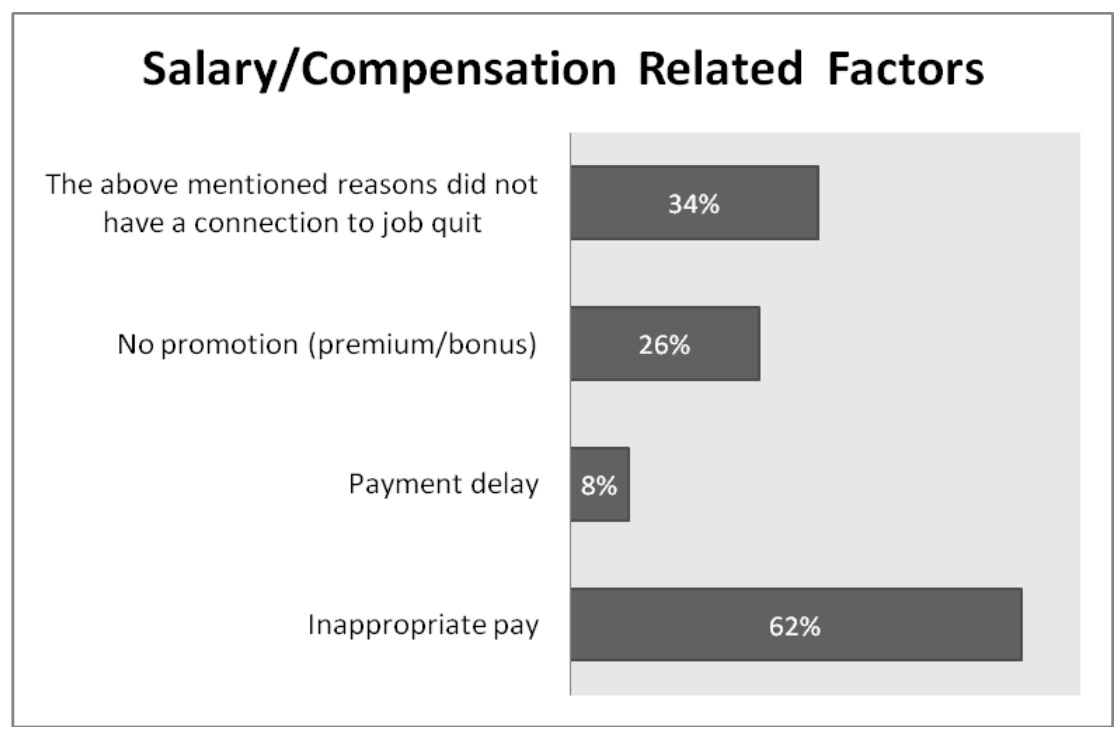

Source: Developed by the Author

\subsection{Labor Conditions}

According to the results of study, the most important thing is when the organization creates a clearly defined function and duties for all employees. Candidate should know what functions he/she is hired for. The review and additions of each function must be accompanied by joint interaction and the increase function should always be linked to the increase of pay. According to the survey results, employees do not pay attention to the terms of contract. It makes a special de-motivating when people work extra hours and does not receive additional pay for it. Often, the employer does not have the right analysis of what kind of function what time needed, and as a rule, staff deficiency can be explained by the employee's time management problem. If the company fails to allocate additional budgets, it should ensure the distribution of functions by auxiliary forces. There can be used the interns auxiliary power. When it is impossible to use vacation it is a big de-motivating for employees, vacation time is required to all employees to be renovated. By the Georgian legislation vacation time defined as 24 working days per year. When employees work on official holidays it speaks on the wrong distribution of work. These factors are closely linked with salary dissatisfaction and in case of often over-work and low wages they start worrying and have to leave the job. 
Table 8. Labor Conditions Related Factors

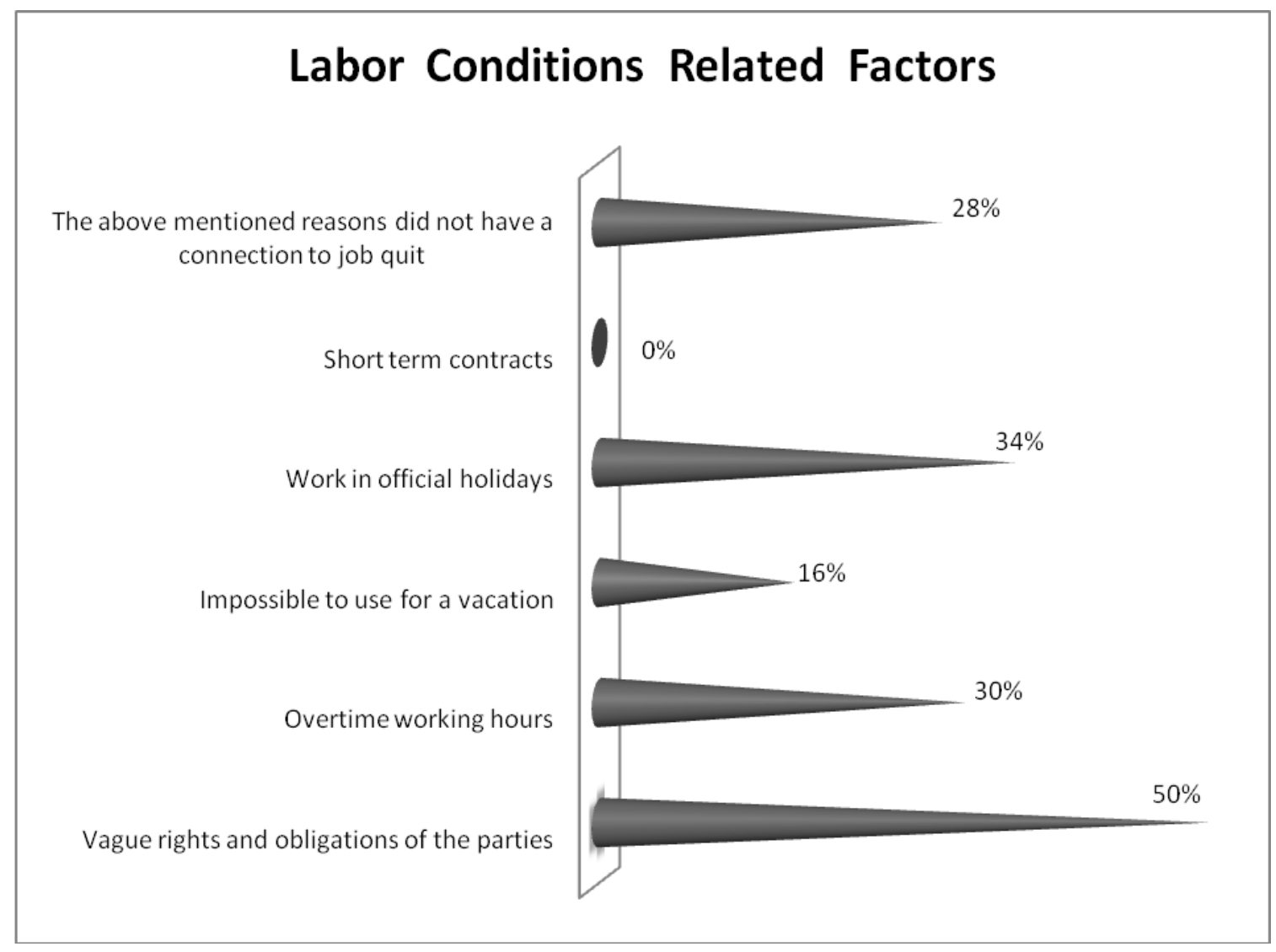

Source: Developed by the Author

\subsection{Job Satisfaction}

People are satisfied with the work with their daily activities, when the new challenges bring diversity when they have certain rights under its functions, when they do not touch the stress, when they have the right of opinion expression etc. Uninteresting and routine activity pushes people to find an interesting job. The employee must have as much of the functionality as it complies with its capabilities. It is important that extra responsibility leads employees' ineptitude. Low involvement is itself a source of dissatisfaction.

When a person does not ask to team members: "how do you think", "how do you like this decision", "tell me otherwise better", etc. any decision is made unilaterally, the employee does not feel the part of the organization causing the thought of leaving. The job needs constant news and changes that needs to learn something new. Otherwise, the worker starts thinking about leaving. Changes are not less important than salaries. The organization should try to justify the expectation from the first day of labor relations. As time passes, the worker looks at the difference between the real situation and the expectations.

In order to minimize the work of dissatisfaction, the employee should not have too much responsibility, which exceeds its competence. 
Table 9. Job Satisfaction Related Factors

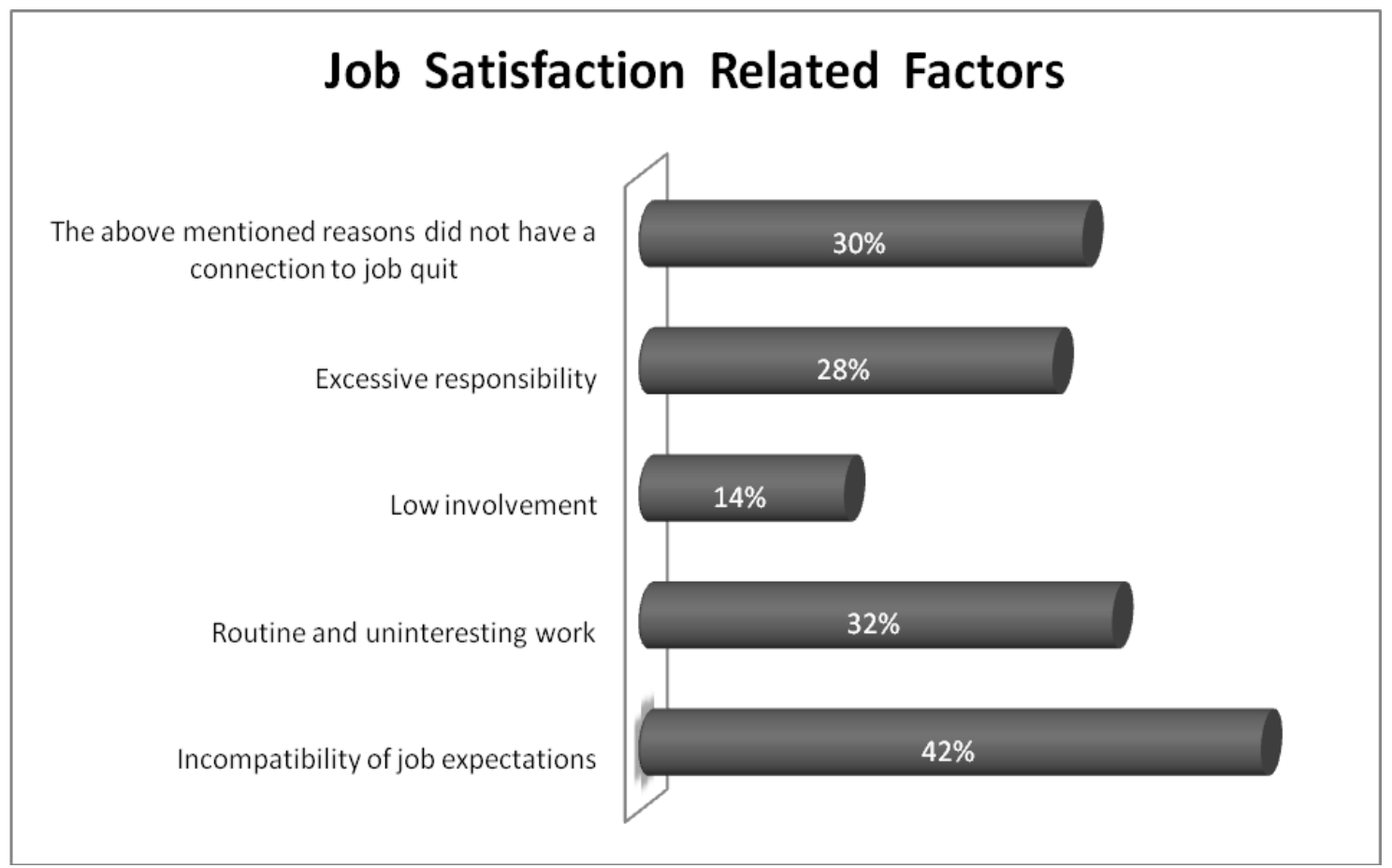

Source: Developed by the Author

\subsection{Management Strategy}

Management strategy and goals is the cornerstone. A strong corporate culture is constructed on this cornerstone when individuals are united with common goals. Since all organizations have its own vital and development cycle, it is important to have the management strategy of organization.

Table 10. Management Strategy Related Factors

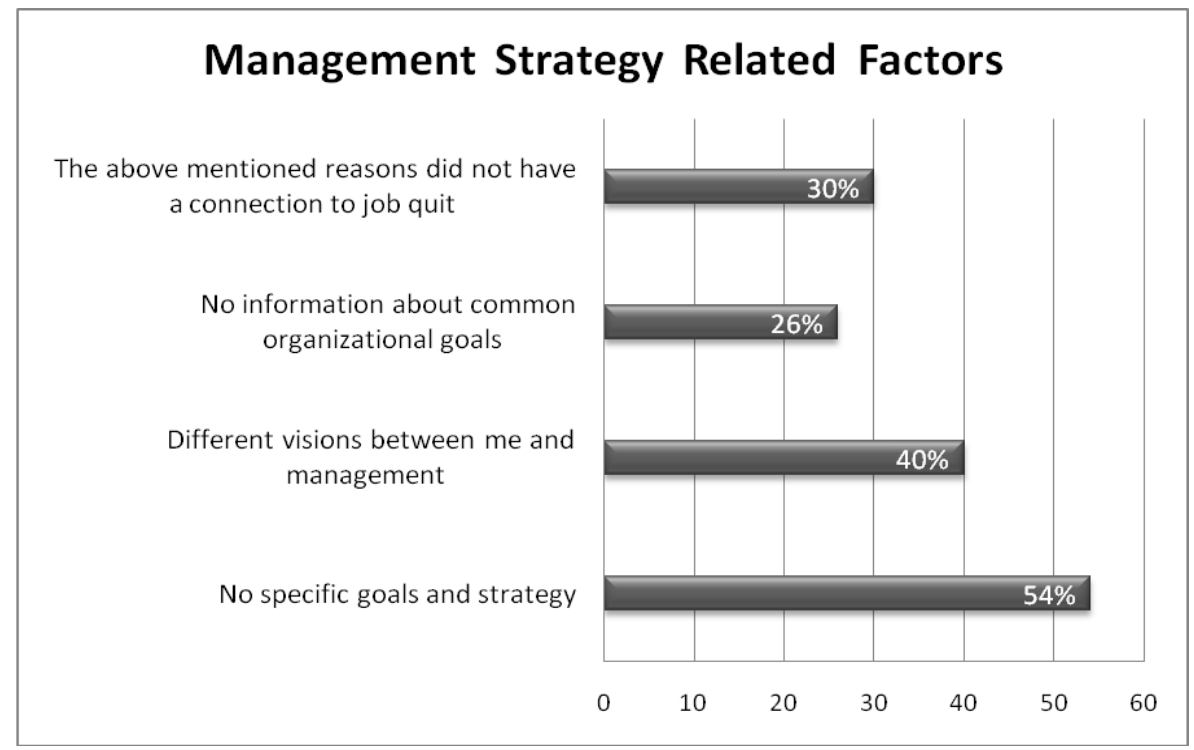

Source: Developed by the Author 


\section{Macrothink Institute ${ }^{T M}$}

Distribution of this strategy, division of the years and months and delivering to each employee is the company's most important task. Each employee needs to understand even the smallest role of what a great task is involved. Thus, knowledge of specific plans and strategies is important for all employees. Not knowledge of common goals is directly related to low engagement or unreasonable daily activities that make it routine for employee. As a rule, for example at recruiting process questions are often by the employer about the candidate's views, opinions, thinking.

On the contrary, it is impossible to determine. The candidate never knows what kind of vision will be disclosed by the head. In fact, the acquaintance of the head becomes a real working environment. When a worker finds out that TOP Management disagrees with his/her vision, employee is forced to leave the job. Therefore, it is better that the employer to be open on selection stages, on the contrary, to assist the candidate to see the employer's real face, to avoid termination of the relationship for this reason.

\subsection{System Management}

The health of the operating system has a positive effect on the motivation of employees. When the system is set up, the employee knows which department works, for which subject matter should be addressed, who is responsible for the operations and all the small steps have its performer, which creates a harmonious working process. When is more bureaucracy in the processes and decisions transfer, instead of independent and decentralized management, each employee is more dissatisfied participating in the process. The process must be followed in a sequence, from the beginning of the action to the end and as easily as possible for read and understand every employee.

Table 11. System Management Related Factors

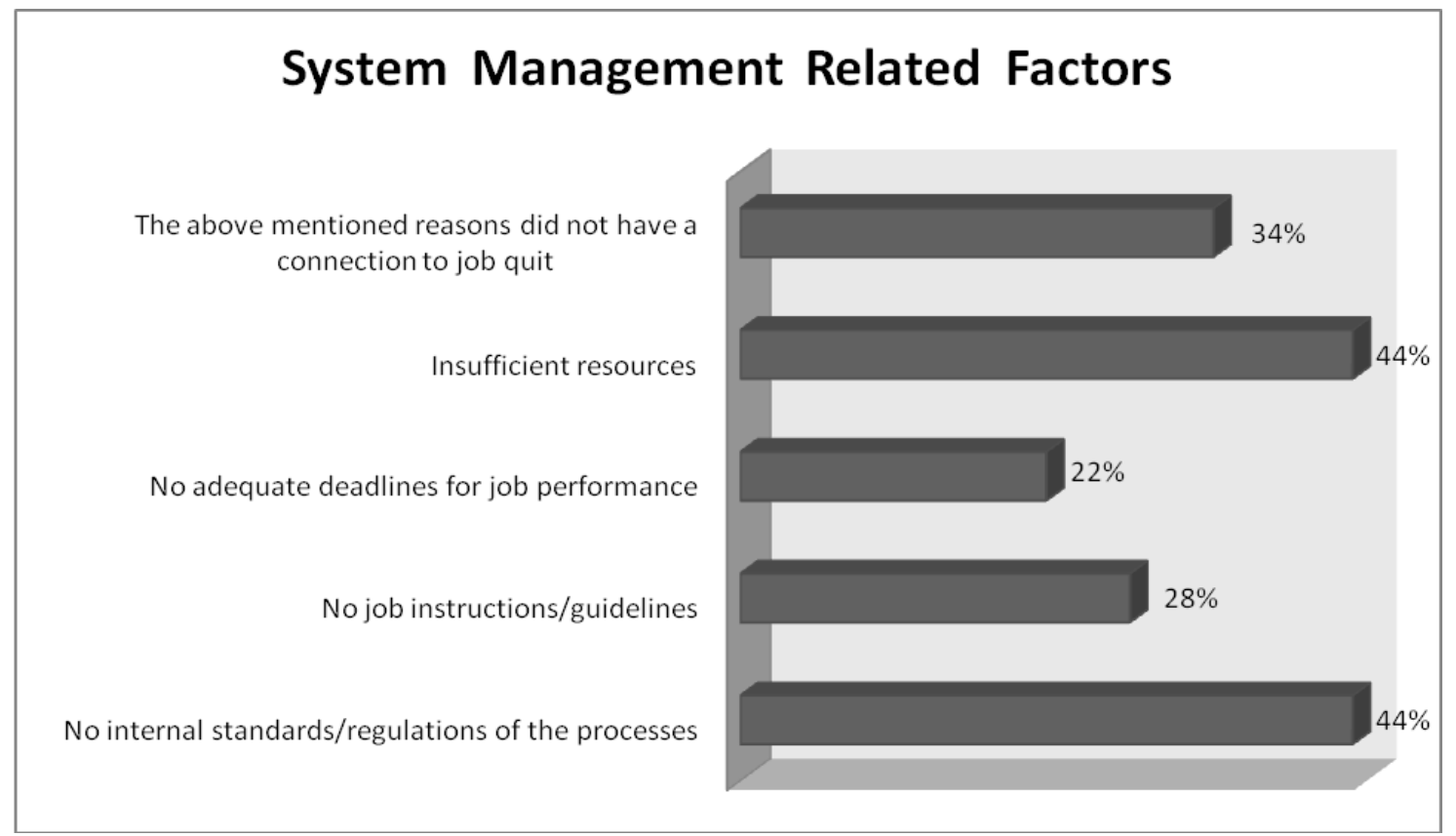

Source: Developed by the Author 
As soon as a new task is written, it is necessary to define the necessary resource, the time frame for the resource, the performer and the adequate deadline. Nowadays, modern information technologies make it easier to simplify the electronic communication channels for distribution and make it easier for management in daily mode of view. On the employee's motivation negatively affecting when it does not recognize the timely performance and vice versa, avoiding from the management to review the reasons for the process delay. The process is more effective when it is focused on listening and reviewing the staff.

\subsection{Job Location}

Moving to work and related benefits is important for the employee. As a rule, large and multifunctional company (production, construction, warehouse, farm, etc.) are located away from city center. Such companies have a large space for employees. The companies located in the city center are relatively small and are distributing employees to the narrow workplace. At the start of the job people are less likely to pay attention to the territorial factor in terms of labor market conditions, but over time their move to a far-off company are becoming more and more problematic.

Table 12. Job Location Related Factors

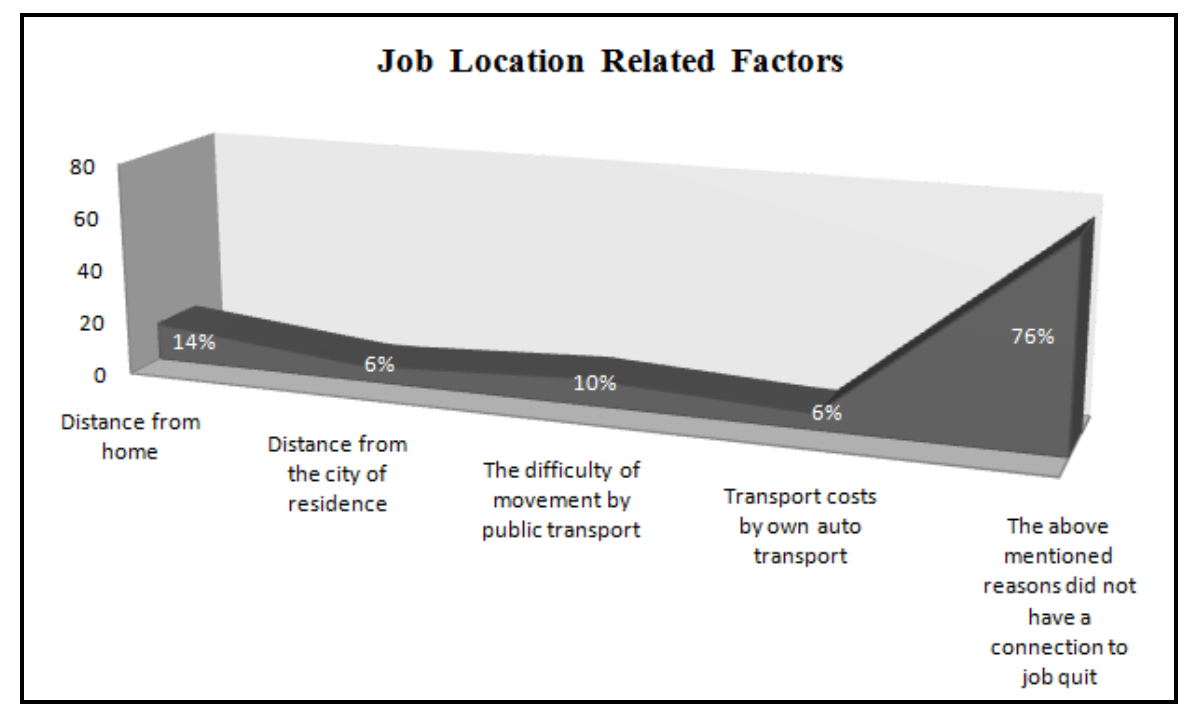

Source: Developed by the Author

According to survey the company does not need to focus special attention on the territorial location. However, the distance from the worker's home to city itself is a constant thought of new job. Over time, the reason is still reflected on a motivated employee. By the Company the best benefit at this time is service by company's transport or refund transportation costs, or the proposal of free taxi service for employees. When the company cares about the employee's comfortable movement at work, the employee is motivated not to pay attention to the territorial distance and stay in the organization for a long time.

\subsection{Company Reputation}

In general, the company's image has a great impact on staff. People are proud to work in a successful and well-known company and on the contrary, when the company has a bad 


\section{Macrothink}

International Journal of Human Resource Studies

ISSN 2162-3058

2019, Vol. 9, No. 2

reputation, people hide that they are members of the company's team. Employees are concerned about the reputation of company, discussing it in the home or outside of the organization, sometimes with social channels spreading internal organizational information. They think about all when are not satisfied with the job and do not feel harmoniously in organization.

Table 13. Company Reputation Related Factors

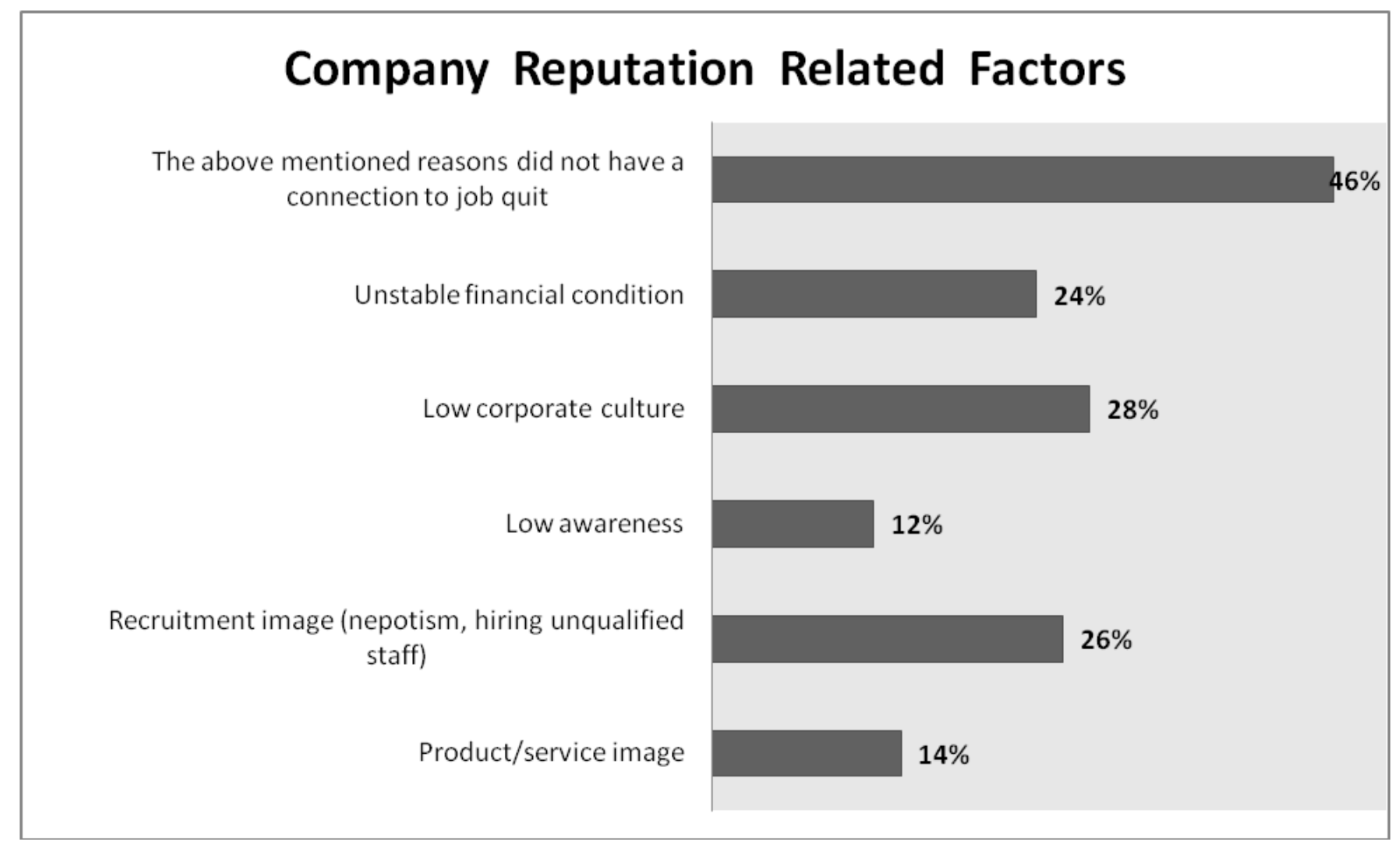

Source: Developed by the Author

When employee has a direct relationship with the management, not transparent recruiting may be reason for leaving the job. For example, the employee believes that instead of own promoting a new employee has been received instead of own promoting someone is promoted and so on. When recruitment image is in indirect connection with the worker, it is not the main reason for job quit decision. It is important to explain the need for each new job. Internal discontent comes when the employee are refused to hire his/her friend or relative.

Employer branding is the strategy for attracting and maintaining talents. Thus, it is logical that people are trying to move from a lesser awareness company to a prestigious employer. The financial crisis will directly reflect the discontent of employees on the fear of their financial stability. In spite of all this, the employer begins to think about the new job immediately.

The low corporate culture and different culture prevents employees from performing their duties and realizing their best ideas. For example, if the new employee is other cultural carrier and the worker is on high position, she/he may be feel the discomfort with its staff and will begin to think about getting out of this culture. 


\subsection{Working Environment}

In the leading companies of the world, special attention is paid to creating a comfortable working environment for employees. In countries where living standards are high and in accordance with pay, people are motivated to create additional harmony in the workplace because they keep them.

Most of the people employed in Georgia think about personal benefits and in case of dissatisfaction (salary, lack of development, unbearable environment and stress, negative attitude and relationships etc.) they do not pay attention to the comfortable space or work room.

Table 14. Working Environment Related Factors

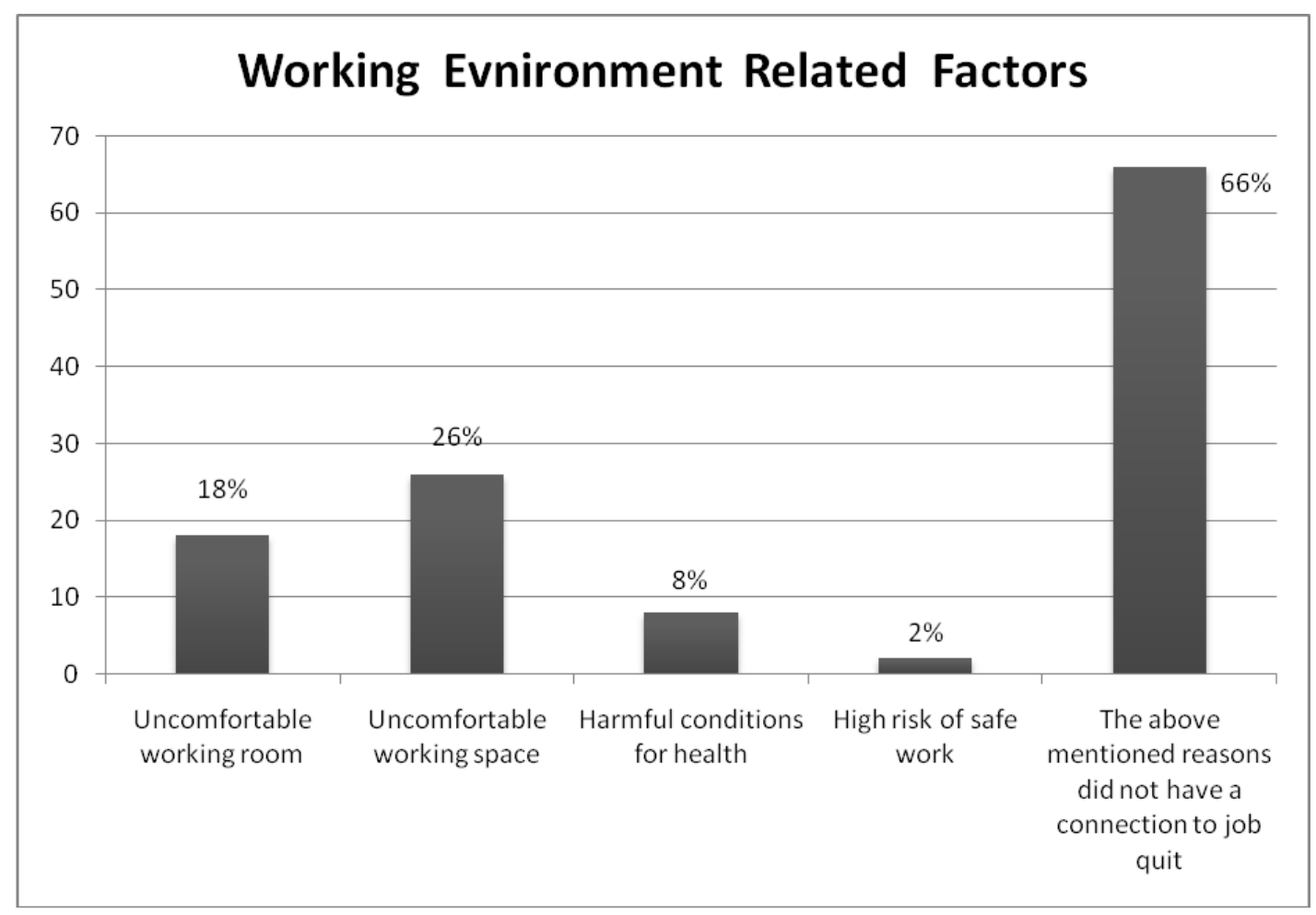

Source: Developed by the Author

\subsection{Personnel Relationship}

The biggest discomfort for the employee causes tense internal personal relationships at work. The relationship with the direct supervisor has a special significance. When there is a greater difference between the direct supervisor and the subordinate in their ideas, in their work quality, in their personal and career development features, there is a more conflict and tensions. Sometimes such a conflict is unnoticed by superiors, and they are secretly underway, which also prevents the positive attitude of the work. When the supervisor does not consider it necessary to listen to the subordinate, there is a gap between them. However, when the worker sees the endless conflicts, unresolved and unacceptable actions, the aggression expressed in each other, not team's dependence on achieving common goals, not support of each other, it is very negatively affecting the employees. The employee is not happy to go to 
work, and he/she is looking for a better environment to solve this suffering. Not collegiality, not a friendly attitude and teamwork between staff require strict supervision of the management, in order not to cause a drain of talent from the organization.

It should be noted that feedback in the modern world is of great importance. With the acceleration of time, the speed of processes has accelerated people in action, and they are no longer waiting at the end of the year to assess the results of the last year's work. Sometimes the heads ignore the feedback issue at all.

Table 15. Personal Relationships Related factors

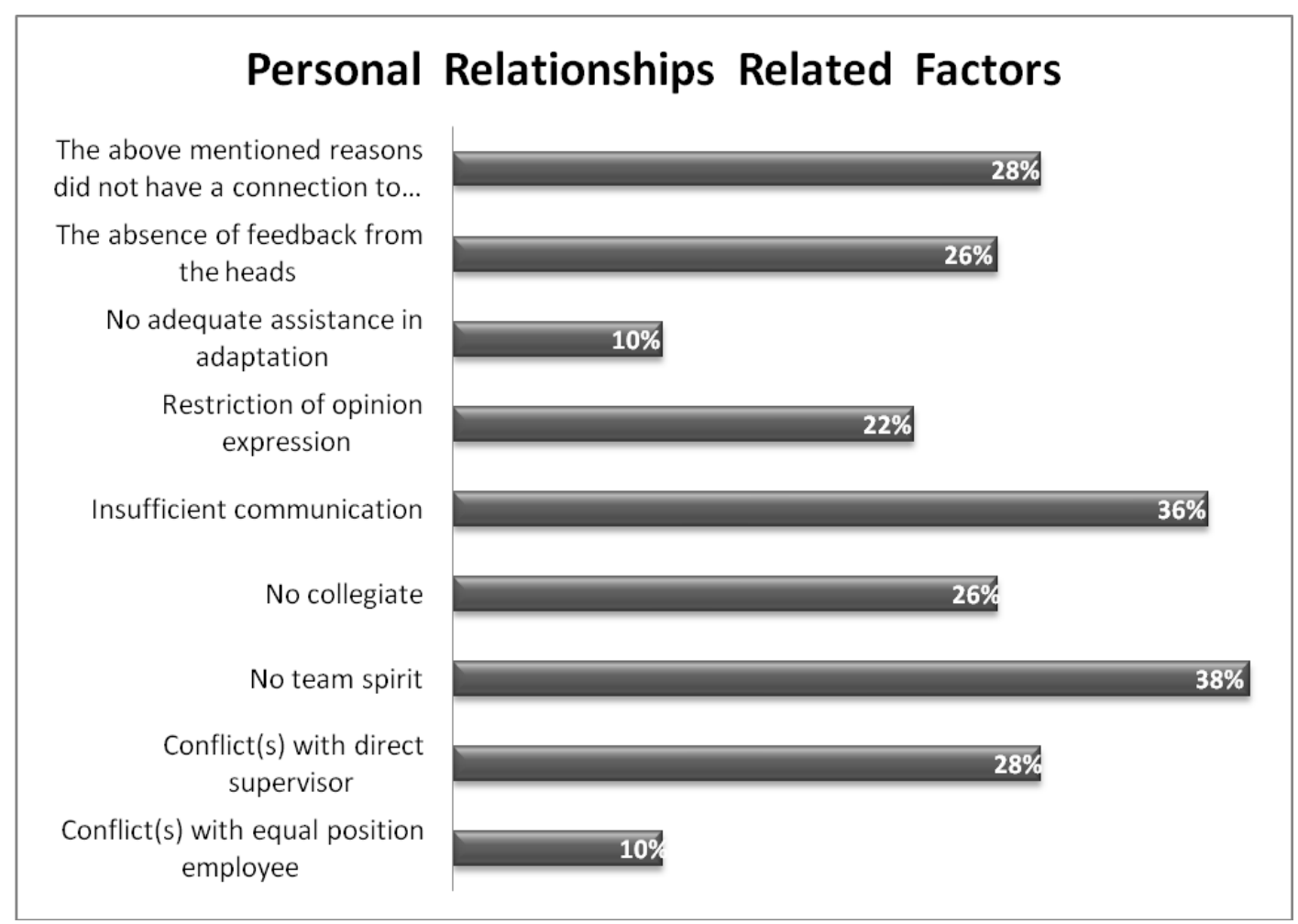

Source: Developed by the Author

There may be several reasons for this: First - when the manager knows about the positive results of worker and does not want to recognize his/her achievement and material encouragement; Second — when the supervisor does not feel the feedback importance; Third - when the head is waiting at the end of the year and the final evaluation. In the meantime, people are already thinking about other job

\subsection{Job Growth/Development}

Often, employers think that the main thing to find the talent is to offer salary and additional benefits. At this time it is important to keep him/her, for which the salary is not enough. Due to the results of survey, for the employee professional development is the greatest importance. Obviously, the development of personnel is not only related to teaching. Employee is rising when comes other challenge being appointed to another position, climbing to a higher level. When there are no ability in the company for promotion competent talents, people are 


\section{Macrothink}

International Journal of Human Resource Studies

ISSN 2162-3058

2019, Vol. 9, No. 2

looking for other possibility to other company. If the company doesn't offer a high level and the relevant salary to the employee, worker will start searching it somewhere else. Establishing an efficient management model by successful teams is a high level of engagement in the organization.

Table 16. Job Growth/Development Related Factors

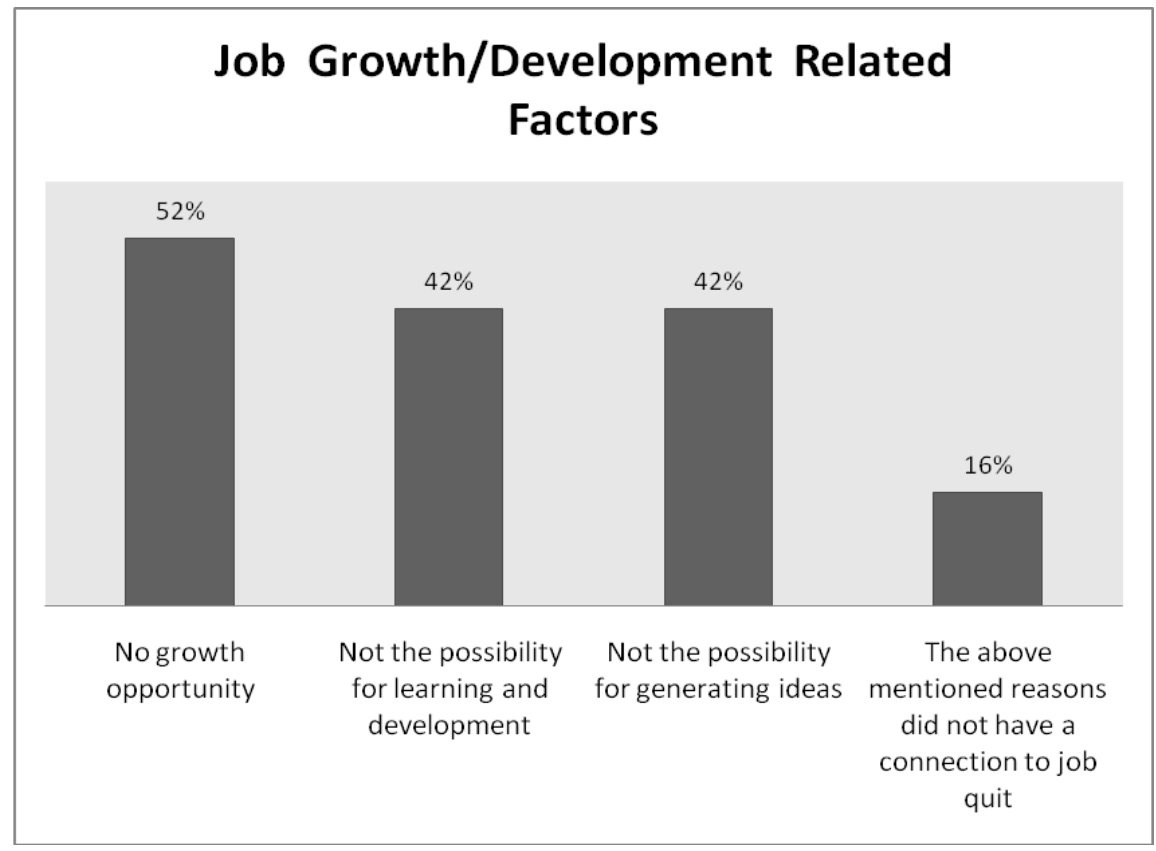

Source: Developed by the Author

\subsection{Motivation System}

The Contents' motivation are based on the internal needs that force people to act and not otherwise. The Processing motivation theory is the behavior of people with perceptions and awareness.

The use of motivation theories are based on human needs and earned salaries. The primary needs are physiological by their nature and are characterized by human birth as a rule. It belongs to the needs of food, water, air etc. The secondary needs are psychological. It includes the need for success, respect and power. The primary needs in humans are genetically engineered, and the secondary will be acquainted with experience.

It is better not to have a motivation system in the organization than to have an unfair, and the employees feel that they are not properly recognized. In the modern era, the employees need not only verbal, but also expressed respect and esteem in the form of material and competing benefits.

Paying a good salary does not determine that the worker is always motivated. $\mathrm{He} / \mathrm{she}$ is asking for recognition of every success in his/her inner work, maximizing its labor potential and experience/education. 
Table 17. Motivation System Related Factors

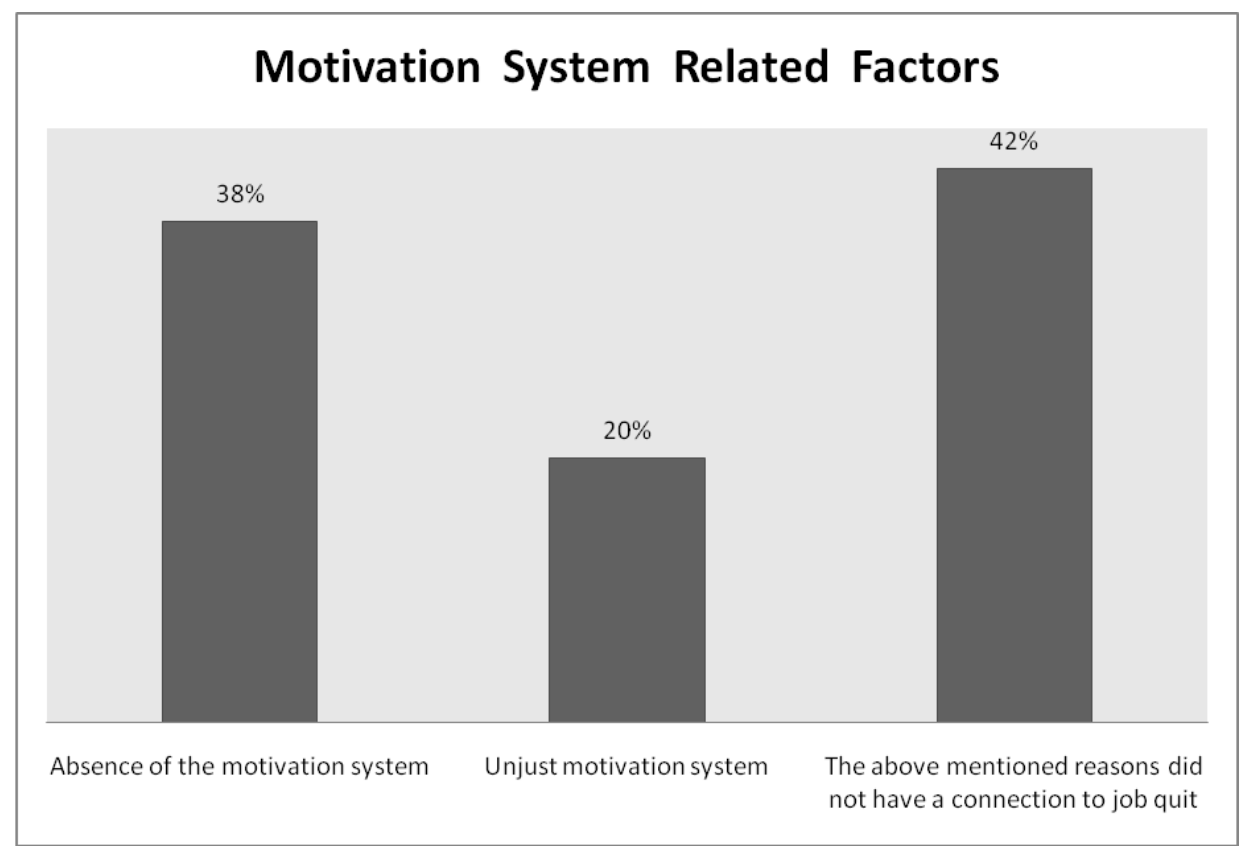

Source: Developed by the Author

\subsection{Performance Appraisal}

The assessment system is a combination of the most hazardous system approaches when each employee needs to understand the role of evaluation and provide transparent and sincere information in favor of the organization.

Table 18. Performance Appraisal Related Factors

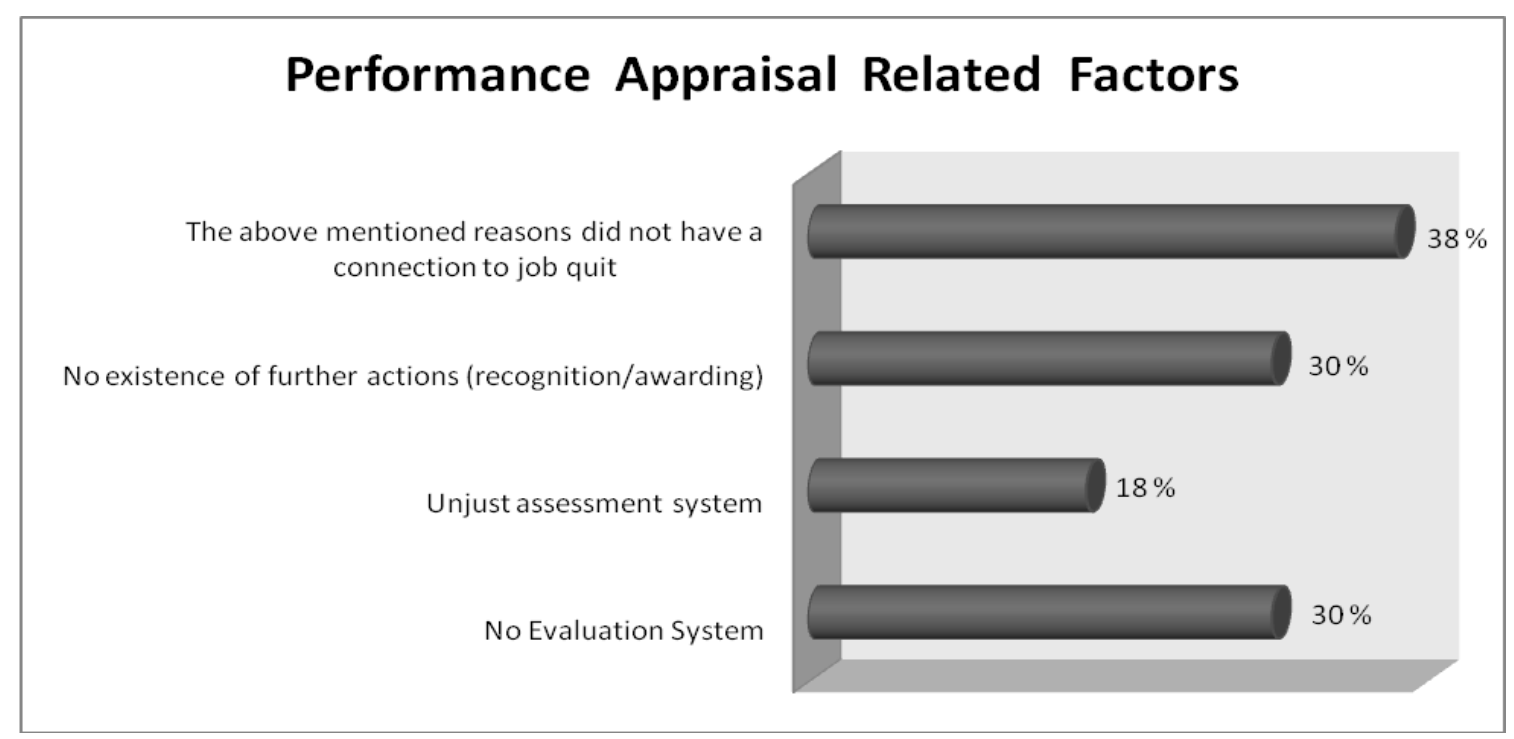

Source: Developed by the Author

As if people only think about two things: first, negatively characterize from those employees 


\section{Macrothink}

International Journal of Human Resource Studies

ISSN 2162-3058

2019, Vol. 9, No. 2

who are less close friends, and they differ and secondly from the employees who are close friends, and they are the same. That is why it is a difficult process to introduce a fair assessment system based on the nature of Georgian human. Also, it is important that assessment system is introduced in order to encourage a worker with positive results and reduce the worker with negative results. If the assessment does not have a purpose, it is only the chaos, confrontation and fear in the organization. It's better, for organization understanding the complexity of performance assessment implementation and get ready for long-term adaptation and step by step explaining management rules.

\subsection{Informational Technology}

IT (Informational Technology) development and innovation are of particular importance for organizations. Where all the process is automated and manual work is less common, people make fewer mistakes and their work time is more productive. The introduction of technologies is significantly related to the financial resources of the organization. The organization should be ready to trust the technology and the quality of the results and staff should be ready to adapt to a new technology platform. Depending on age peculiarities of generations, part of the employees still prefer to work manually, part of the workforce only works with automated software to feel comfortable. The acquisition of new technologies is related to new programs and challenges that can be used to retain the employee.

Table 19. Technology Related Factors

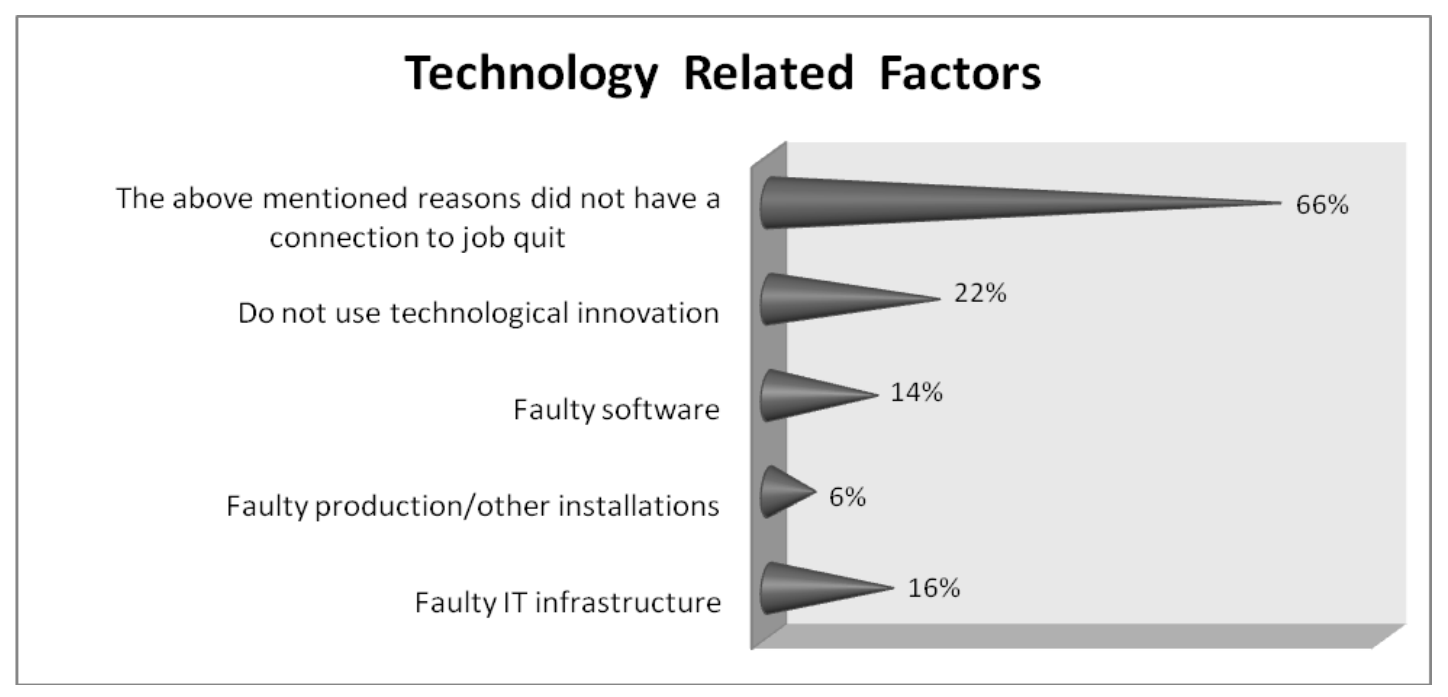

Source: Developed by the Author

\section{Conclusion}

The purpose of qualitative and quantitative research is to find out what factors affect on employees' decision to leave the job. Large number of employees' drain indicator mostly decreases the productivity of the remaining employees. In order to support talented staff the organizations need advance HR policies that are based on the effectiveness of various directions. 
These directions preferably are:

(1) Transparency and competence based recruiting process

(2) Fair compensation and benefit system

(3) Discover talents and plan their successful career

(4) Care for the development of the organization

(5) Care for permanent development of employees

(6) Care for employee interest and involvement

(7) Employee drain and other data persistent analytics

(8) Care for organizational culture

(9) Timely recognition of staff achievements.

From the results obtained above mentioned key points are revealed, which is important for TOP management and HR professionals, to maximize the profit of the organization. There are studied all the possible factors that affect employees in Georgia. It is necessary to analyze these factors and considering it to promote business efficiency. Within framework of diploma thesis the main goal is to find out the reasons for the employee dissatisfaction, which causes voluntary outflow and requires special warnings from the organization.

Although research is conducted in Georgia and cases with explored factors took place within the country, however, observation and study result shows importance of employee retention for any organization, for mobilization of workforce, for reduction of expenditures, for growth of talents and use human resources potential for business success.

The knowledge and experience about employee turnover from researchers accumulated over the years and centuries have been linked to this. Some models or methods have undergone transformation over time, but all the major initial theories raised nowadays is the challenges for effective managing of human resources. Together with technological advances and labor trends in the world, the demands of human beings are changed. Along with the passage of time, management approaches have changed over staff. Bureaucratic management models have been changed step-by-step for the study of human behavior and psychological approaches.

This study demonstrates that the level of social development and material culture has been elevated contributing to the need for socialization in the internet world. Individuals are very close to each other. The consciousness of human as an employee was raised. The employee is quite familiar with the rules and standards of labor relations. This led the fact that organizations firstly have the crisis to find a talent, after that to maintaining them. Considering the above, organizations on one hand should have constantly orientation to business profitability, its development in the digital world under strong competition, on second hand to maintain staff and mobilize qualified employees with the permanent individual approaches. 


\section{Macrothink}

International Journal of Human Resource Studies

ISSN 2162-3058

2019, Vol. 9, No. 2

Experts of psychology have created a number of theories of motivation for years, whose trace is practiced today at every step. In order to eliminate the employee's dissatisfaction and solving one problem does not mean that employee is motivated and satisfied. Of course, all the theories remain theoretically in terms of non professionalism and poor working environment. Nowadays, employees are not afraid of losing their jobs at the background of virtual social space development. Information on new jobs is available to everyone. Moreover, they are free to express their dissatisfaction through social channels and thus they easily damage the company's reputation. That is why preliminary studies and timely response to dissatisfaction are required.

Based strong corporate spirit the organization needs to build personnel policy, that will improve the quality of work performed by the workforce and that will bring better results for business. Managers should evaluate the staff in a much deeper emotional position.

With globalization, jobs became much more diverse. People have an inner demand to overthrow some activities simultaneously. The organization's should support to their employees' individual work condition, give them flexible work schedule that has a great importance.

New generation's employees are increasingly trying their self-realization. The individual's own perception of needs is his/her motivation initiated. If the main need is not satisfied, the millennial worker will quickly use another way such as leaving the job. The organization needs special efforts to maintain successful talents. According to the results of studies, organizations should consider the presented conclusive recommendations to take into consideration the current trends and ensure the individual's expectations accordingly.

\section{Recommendations}

According to the research important 9 factors have been identified to avoid employee voluntary turnover:

Most important:

(1) Relevant Salary/Compensation

(2) Opportunity of professional growth

(3) Harmonious relationships with supervisor

(4) Work-life balance

(5) Knowledge of specific strategies and goals of organization

(6) To have process guidelines

(7) Effective communication in organization

(8) To provide required resources

(9) Clearly defined functions.

The points are equally important, but the first 5 is particularly important. Thus, the organization should try to minimize voluntary turnover and use the motivated and development-oriented human resources for business success. 
These reommendations may also be useful for other countries, for those who are in similar conditions (post-soviet countries). Since Georgia is a dynamically developing country, situation in organizations it is related to the process of adaptation of organizations and individuals. Consequently, it is important to study the factors in the organizations that are causing employee dissatisfaction. The organization should always try to trequently conduct employees' motivation, satisfaction and engagement survey. To ensure effective work of organizations, it is necessary to manage modern methods of motivation, taking into account the personal characteristics of employees. Lee Iacocca (1980) said "Management is nothing more than motivating people".

Within the scope of new research, explored factors that caused employee voluntary turnover is very important to analyze for TOP managers, business owners, HR professionals and individuals interested in organizational development in Georgia.

\section{Acknowledgement}

I would like to express my profound gratitude to my research supervisor Mr. GEORGE BAGHATURIA (Professor of Georgian Technical University - Public Administration and Electronic Business Department; Invited Professor of Warsaw Management University Program Department of Tbilisi; Coordinator of Management at International Black Sea University of Georgia) for his unconditional support and technical knowledge he has provided me at every stage of my research work. Without his support and supervision this paper would not have been possible. I am thankful all of my HR colleagues who contributed in my personal and professional growth through research process.

\section{Glossary}

$\begin{array}{ll}\text { AIHR } & \text { Analytics in HR - HR Analytics Academy } \\ \text { ASA } & \text { Attraction, Selection, Attrition } \\ \text { CEO } & \text { Chief Executive Officer } \\ \text { DDI } & \text { Development Dimensions International } \\ \text { HC } & \text { Human Capital } \\ \text { HR } & \text { Human Resources } \\ \text { IGEN } & \text { Internet Generation } \\ \text { IQ } & \text { Intention to Quit } \\ \text { IT } & \text { Informational Technology } \\ \text { SHRM } & \text { Society for Human Resource Management } \\ \text { TOP } & \text { Most Important Executives in an Organization } \\ \text { VUCA } & \text { Volatile, Uncertain, Complex and Ambiguous }\end{array}$

\section{References}

Allen, D. G. (2008). Retaining Talent. A Guide to Analyzing and Managing Employee Turnover. SHRM Foundation's Effective Practice Guidelines Series. [Online] Available: https://www.shrm.org/hr-today/trends-and-forecasting/special-reports-and-expert-views/Docu ments/Retaining-Talent.pdf 


\section{$\triangle 1$ Macrothink}

International Journal of Human Resource Studies

ISSN 2162-3058

2019, Vol. 9, No. 2

Armstrong, M., \& Taylor, S. (2017) Armstrong's Handbook of Human Resource Management Practice. 14th Edition. https://doi.org/10.4135/9781483386874.n31

Attraction-Selection-Attrition Model. (n.d.). The SAGE Encyclopedia of Industrial and Organizational Psychology, 2nd Edition.

Bennett, N., \& Lemoine, J. (2014). What a Difference a Word Makes: Understanding Threats to Performance in a VUCA World. SSRN Electronic Journal.

Bersin, J. (2015, January 26). Becoming irresistible: A new model for employee engagement. Deloitte Insight. Deloitte Review Issue 16. [Online] Available: https://www2.deloitte.com/insights/us/en/deloitte-review/issue-16/employee-engagement-stra tegies.html

Biernacki, P., \& Waldorf, D. (1981). Snowball Sampling: Problems and Techniques of Chain Referral Sampling. Sociological Methods \& Research, 10(2), 141-163. https://doi.org/10.1177/004912418101000205

Byrne, Z. S. (2014). Understanding Employee Engagement. https://doi.org/10.4324/9780203385944

Dessler, G. (2013) Human Resource Management, 13th Edition. Florida International University, Pearson Education, Inc., publishing.

Goler, L., \& Gale, J., \& Harrington, B., \& Grant, A. (2018, January 11) Why People Really Quit Their Jobs. Harvard Business Review. [Online] Available: https://hbr.org/2018/01/why-people-really-quit-their-jobs

Hom, P. W., \& Griffeth, R. W. (1991). Structural equations modeling test of a turnover theory: Cross-sectional and longitudinal analyses. Journal of Applied Psychology, 76(3), 350-366. https://doi.org/10.1037/0021-9010.76.3.350

Klinge, C. M. (2015). A Conceptual Framework for Mentoring in a Learning Organization. Adult Learning, 26(4), 160-166. https://doi.org/10.1177/1045159515594154

Luthans, F., Rhee, S., Luthans, B. C., \& Avey, J. B. (2008). Impact of behavioral performance management in a Korean application. Leadership \& Organization Development Journal, 29(5), 427-443. https://doi.org/10.1108/01437730810887030

March, J. G. (1991). Exploration and Exploitation in Organizational Learning. Informs Institute for operations research and management sciences, 71-87. https://doi.org/10.1287/orsc.2.1.71

Mowday, R. T., \& Koberg, Ch. S., \& McArthur A. W. (1984). The Psychology of the Withdrawal Process: A Cross -Validation Test of Mobley's Intermediate Linkages Model of Turnover in Two Samples. The Academy of Management Journal, 1, 79-94.

Price, J. L., \& Mueller, C. W. (1981). A Causal Model of Turnover for Nurses. The Academy of Management Journal, 3, 543-565. 


\section{Macrothink}

International Journal of Human Resource Studies

ISSN 2162-3058 2019, Vol. 9, No. 2

Saridakis, G. (n.d.). Introduction: the state of employee turnover. Research Handbook on Employee Turnover, 1-4. https://doi.org/10.4337/9781784711153.00005

Schneider, B. (1987). The people make the place. Department of Psychology, University of Maryland, College Park, MD 20742. https://doi.org/10.1111/j.1744-6570.1987.tb00609.x

Smart, M., \& Chamberlain, A. (2016). Why Do Workers Quit? The Factors that Predict Employee Turnover. Research Report. Glassdoor Economic Research. [Online] Available: https://www.glassdoor.com/research/app/uploads/sites/2/2017/02/WhyDoWorkersQuit_Glass door.pdf

Torrington, D., \& Hall, L., \& Taylor, S. (2005). Sixth edition of Human Resource Management. England. Pearson Education Limited.

University of TWENTE, Netherlands. (n.d.). Attraction-Selection-Attrition Framework: Understanding Organizational Behavior. [Online] Available: https://www.utwente.nl/en/bms/communication-theories/sorted-by-level/meso/Attraction-Sele ction-Attrition_Framework(ASA)/

Vulpen, E. V. (n.d.). 17 Recruiting Metrics You Should Know About. [Online] Available: https://www.analyticsinhr.com/blog/recruiting-metrics/?utm_source=activecampaign\&utm_m edium=email\&utm_campaign=welcome-sequence\&utm_content=metrics-reporting

Vulpen, E. V. (n.d.). What Drives Employee Turnover? Part 2. Analytics in HR. [Online] Available: https://www.analyticsinhr.com/blog/what-drives-employee-turnover/

Wanous, J. P., Poland, T. D., Premack, S. L., \& Davis, K. S. (1992). The effects of met expectations on newcomer attitudes and behaviors: A review and meta-analysis. Journal of Applied Psychology, 77(3), 288-297. https://doi.org/10.1037/0021-9010.77.3.288

\section{Copyright Disclaimer}

Copyright for this article is retained by the author(s), with first publication rights granted to the journal.

This is an open-access article distributed under the terms and conditions of the Creative Commons Attribution license (http://creativecommons.org/licenses/by/4.0/). 